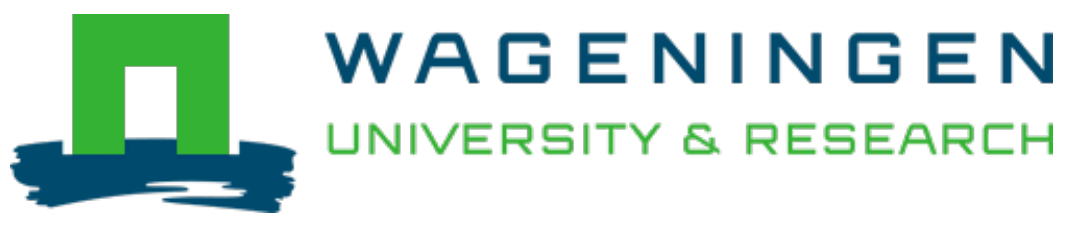

\title{
Management of Diseases Caused by Pectobacterium and Dickeya Species
}

Plant Diseases Caused by Dickeya and Pectobacterium Species

Wolf, J.M.; Boer, S.H.; Czajkowski, R.L.; Cahill, Greig; Gijsegem, Frédérique et al

https://doi.org/10.1007/978-3-030-61459-1_6

This article is made publicly available in the institutional repository of Wageningen University and Research, under the terms of article $25 \mathrm{fa}$ of the Dutch Copyright Act, also known as the Amendment Taverne. This has been done with explicit consent by the author.

Article $25 \mathrm{fa}$ states that the author of a short scientific work funded either wholly or partially by Dutch public funds is entitled to make that work publicly available for no consideration following a reasonable period of time after the work was first published, provided that clear reference is made to the source of the first publication of the work.

This publication is distributed under The Association of Universities in the Netherlands (VSNU) 'Article $25 \mathrm{fa}$ implementation' project. In this project research outputs of researchers employed by Dutch Universities that comply with the legal requirements of Article $25 \mathrm{fa}$ of the Dutch Copyright Act are distributed online and free of cost or other barriers in institutional repositories. Research outputs are distributed six months after their first online publication in the original published version and with proper attribution to the source of the original publication.

You are permitted to download and use the publication for personal purposes. All rights remain with the author(s) and / or copyright owner(s) of this work. Any use of the publication or parts of it other than authorised under article $25 \mathrm{fa}$ of the Dutch Copyright act is prohibited. Wageningen University \& Research and the author(s) of this publication shall not be held responsible or liable for any damages resulting from your (re)use of this publication.

For questions regarding the public availability of this article please contact openscience.library@wur.nl 


\title{
Chapter 6 \\ Management of Diseases Caused by Pectobacterium and Dickeya Species
}

\author{
Jan M. van der Wolf, Solke H. De Boer, Robert Czajkowski, Greig Cahill, \\ Frédérique Van Gijsegem, Triona Davey, Brice Dupuis, John Ellicott, \\ Sylwia Jafra, Miriam Kooman, Ian K. Toth, Leah Tsror, Iris Yedidia, \\ and Jacquie E. van der Waals
}

\begin{abstract}
Management of soft rot Pectobacteriaceae (SRP) is a challenge as there are no control agents available and no effective resistance present in commercial cultivars. In addition, many species of SRP have a broad host range and spread via rotten plant material takes place readily. In this chapter, the possibilities for disease management are outlined. Management is mainly based on seed certification to limit
\end{abstract}

J. M. van der Wolf $(\varangle)$

Wageningen University and Research, Business Unit Biointeractions and Plant Health, 6700 AA Wageningen, The Netherlands

e-mail: Jan.vanderWolf@wur.nl

S. H. De Boer

CFIA Charlottetown Laboratory, Charlottetown, PE, Canada

R. Czajkowski · S. Jafra

University of Gdansk, IFB UG and MUG, Gdansk, Poland

G. Cahill

SASA, Edinburgh, Scotland, UK

F. Van Gijsegem

Sorbonne Université, INRAE, Paris, France

T. Davey $\cdot$ J. Ellicott

SASA, Edinburgh, UK

B. Dupuis

Agroscope, PPP, Nyon, Switzerland

M. Kooman

Dutch General Inspection Service, Emmeloord, The Netherlands

I. K. Toth

James Hutton Institute, Invergowrie, Scotland, UK

L. Tsror

Agricultural Research Organization, Gilat, Israel

I. Yedidia

Agricultural Research Organization, Volcani Center, Israel

J. E. van der Waals

University of Pretoria, Pretoria, South Africa 
the risks of using infected planting material, and on hygiene and cultivation practices that reduce cross-contamination within and between seed lots. Balanced nutrition also supports the suppressiveness of crops against SRP. Experimental data show that inoculum in seed tubers can be reduced by thermotherapy and the use of biocides. Under controlled conditions, application of seed potatoes with biocontrol agents has showed promising results but few data are present on the efficacy of biocontrol in the field. Resistance in wild Solanum species against SRP has been found but to date no genes have been transferred to cultivars. However, new breeding technologies, such as CRISPR/CAS 9 and the use of true potato seed (TPS), will give us new perspectives on the generation of resistant cultivars.

\subsection{Introduction}

The control of plant diseases caused by soft rot Pectobacteriaceae (SRP) is highly challenging. Until now, no commercially available control agents have been developed to effectively control SRP infections in agriculturally important crops. In addition, no host crops immune to SRP have been developed, while the use of SRPresistant crops generated using biotechnology, although promising, is not widely accepted. In potato, the use of SRP-free certified planting material, in combination with the application of adequate cultural and hygienic measures, is still the most effective strategy to reduce contamination and disease prevalence. Within the certification scheme, the use of minitubers grown from pathogen-free in vitro plants significantly contributes to the management of the disease. Nevertheless, infections in the first generations frequently occur, whereas the main source of initial infection is still unknown despite the identification of several potential infection sources (see Chap. 3). In this chapter, testing and certification of planting material, the use of cultivation measures and hygiene, options to treat plant material, and the perspectives for resistance breeding will be discussed for potato (Sects. 6.2-6.6) and to a lesser extent, due to lack of available information, other hosts including chicory, Chinese cabbage and ornamental crops (Sect. 6.7).

\subsection{Seed Testing and Certification in Potato}

The health, vigour and yield of a potato crop are strongly influenced by the quality of the seed tubers (Haverkort and Struik 2015). Seed potatoes are generally the most expensive input for a seed crop (www.fao.org/potato-2008/en/potato/cultiv ation.html) but a high marketable yield can offset these costs, and planting healthy seed potatoes is therefore a key factor in maximising the marketable yield of a crop.

Potato is a vegetatively propagated crop and, unlike true seed propagation, such plants are prone to disease and deterioration in quality with each propagation cycle. Many potato-producing countries mitigate this risk using a certification program, 
which provides assurance to customers that seed potatoes meet specified minimum health standards.

Certification is the process of assuring the quality of seed potatoes that are being marketed. Seed potato certification programs ensure the production and supply of seed potatoes in which disease, predominantly seed-borne, has been monitored, controlled and maintained below a threshold that could cause significant losses to customers (www.unece.org/trade/agr/standard/potatoes). The United Nations Economic Commission for Europe (UNECE) acknowledges that strict tolerances at the growing crop and tuber inspections are an important tool in controlling blackleg in certified seed.

\subsubsection{Certification and Testing in Europe}

Certification is under official control of the government designated authority in the producing country and many countries have their own national standards that may be stricter than regulated standards. In the EU, certification is regulated by Directives 2014/20/EU and 2014/21/21/EU. Seed certification programs normally start with the production and multiplication of in vitro pathogen-free microplants (nuclear stock). Nuclear stock microplants undergo an extensive testing program to ensure freedom from disease. These microplants are multiplied in a protected facility to produce Prebasic Tissue Culture (PBTC) minitubers, to comply with International Standards for Phytosanitary Measures (ISPM) guidelines. These PBTC minitubers are the input seed for the first field grown generation of seed potatoes. In the EU, seed potato crops are categorised depending on the health and the field generation. These categories are Pre-basic (PB), Basic and Certified as recommended in the UNECE standard for seed potatoes (UNECE 2018; www.unece.org/trade/agr/standard/potatoes). Seed certification programs typically restrict the maximum number of generations permitted for seed crops. As the number of field generations increases, the disease tolerance applicable to each grade relaxes slightly to account for each additional propagation cycle (Table 6.1).

Crops entered for certification are inspected at least twice during the growing season. A random representative sample of plants is inspected for pathological and physiological faults and the incidence of disease is expressed as a percentage of the crop. Many diseases and faults can be controlled through roguing to ensure the crop meets the required tolerances at inspection. Roguing is the removal of potato plants that are atypical of the cultivar in appearance or diseased, including plants presenting blackleg or wilting symptoms (Kerlan et al. 1987). Effective roguing ensures that sources of infection are removed from the crop during the growing season and less symptomatic material is harvested with the crop. This reduces disease spread and losses in storage. Certification is normally based on a visual assessment of the crop. However, some countries choose to use laboratory testing in addition to a visual inspection for some diseases, particularly virus related, to detect and control latent or late infections. Tables 6.1 and 6.2 detail the tolerances for blackleg and tuber soft 
Table 6.1 Tolerances for blackleg incidence (\%) following field inspection of a seed potato crop. Table compares minimum conditions stipulated in EU Directives with national regulations of the top 5 (by area) seed potato producing countries in the EU

\begin{tabular}{|c|c|c|c|c|c|c|c|}
\hline \multirow{3}{*}{$\begin{array}{l}\text { Category } \\
\text { Grade/Class }\end{array}$} & \multicolumn{7}{|c|}{ Union grade } \\
\hline & \multicolumn{2}{|c|}{ Pre-basic } & \multicolumn{3}{|c|}{ Basic } & \multicolumn{2}{|c|}{ Certified } \\
\hline & РBTC & PB & $S$ & SE & $\mathrm{E}$ & A & B \\
\hline $\mathrm{EU}$ & 0.0 & 0.0 & 0.1 & 0.5 & 1.0 & 2.0 & 4.0 \\
\hline UNECE & 0.0 & 0.0 & N/A & 0.5 & 1.0 & 1.5 & 2.0 \\
\hline The Netherlands & 0.0 & 0.0 & 0.0 & 0.0 & $0^{\mathrm{a}}$ & 0.03 & 0.1 \\
\hline France & 0.0 & 0.0 & 0.0 & 0.0 & 0.5 & 1.0 & 1.0 \\
\hline Germany & 0.0 & 0.0 & 0.1 & 0.4 & 0.6 & 1.0 & 1.2 \\
\hline UK (Scotland) & 0.0 & 0.0 & 0.1 & 0.5 & 1.0 & N/A & N/A \\
\hline Poland & 0.0 & 0.0 & 0.1 & 0.5 & 1.0 & 2.0 & 4.0 \\
\hline
\end{tabular}

${ }^{\mathrm{a} S p o r a d i c} 1 \mathrm{plant} / \mathrm{ha}$

$\mathrm{N} / \mathrm{A}=$ not applicable

Table 6.2 Tolerances for tuber soft rot (\%) applicable to lots prior to marketing a seed potato crop based on visual inspections. Table compares minimum conditions stipulated in EU Directives with national regulations of the top 5 (by area) seed potato producing countries in the EU

\begin{tabular}{|c|c|c|c|c|c|c|c|}
\hline \multirow{3}{*}{$\begin{array}{l}\text { Category } \\
\text { Grade/Class }\end{array}$} & \multicolumn{7}{|c|}{ Union grade } \\
\hline & \multicolumn{2}{|c|}{ Pre-basic } & \multicolumn{3}{|c|}{ Basic } & \multicolumn{2}{|c|}{ Certified } \\
\hline & PBTC & PB & S & SE & $\mathrm{E}$ & A & B \\
\hline EU & 0.0 & 0.2 & 0.2 & 0.2 & 0.2 & 0.2 & 0.2 \\
\hline UNECE & 0.0 & 0.2 & 0.5 & 0.5 & 0.5 & 0.5 & 0.5 \\
\hline The Netherlands & 0.0 & $0.0^{\mathrm{a}}$ & $0.0^{\mathrm{a}}$ & $0.0^{\mathrm{a}}$ & $0.0^{\mathrm{a}}$ & $0.0^{\mathrm{a}}$ & $0.0^{\mathrm{a}}$ \\
\hline France & 0.0 & 0.2 & 0.2 & 0.2 & 0.2 & 0.2 & 0.2 \\
\hline Germany & 0.0 & 0.2 & 0.2 & 0.2 & 0.2 & 0.2 & 0.2 \\
\hline Scotland $^{b}$ & 0.0 & 0.2 & 0.2 & 0.2 & 0.2 & N/A & N/A \\
\hline Poland & 0.0 & 0.2 & 0.2 & 0.2 & 0.2 & 0.2 & 0.2 \\
\hline
\end{tabular}

${ }^{\mathrm{a}} 1$ tuber $/ 250 \mathrm{~kg}$ for all classes, Dickeya tolerance NIL

${ }^{\mathrm{b}}$ Dickeya tolerance NIL

$\mathrm{N} / \mathrm{A}=$ not applicable

rot applied at growing crop and lot inspections for the top 5 seed potato producing countries in the EU for blackleg and soft rot, respectively.

There are no official post-harvest diagnostic testing programs for SRP, although advisory testing is offered in some countries for management purposes. In a pilot study, the Netherlands experimented with obligatory post-harvest tests for blackleg causing SRP between 2012 and 2018. All marketable PB and S class seed material was tested for SRP by qPCR. The objective of the experiment was to support farmers in selecting $\mathrm{PB}$ and $\mathrm{S}$ class seed in order to reduce the incidence of blackleg in the 
seed potato chain. Initial results showed a clear correlation between latent infection in the sample and blackleg symptoms in the field in the following year. However, this correlation varied between the different SRP, possibly due to variation in virulence, resulting in the test being deemed unsuitable for certification purposes.

Although certification schemes in most countries are similar in their approach to the management of blackleg, their regulations account for local plant health pressures and there is flexibility to adapt the scheme accordingly.

\subsubsection{Certification and Testing in Canada}

To impede introduction of foreign pests, Canada limits entry of potatoes for planting to tissue-cultured plantlets, except from the US. Imported plantlets are screened within a Potato Post-Entry Quarantine (PPEQ) Program operated by the Canadian Food Inspection Agency (CFIA) to ensure freedom from all pathogens, including blackleg- and soft rot-causing bacteria. Laboratory testing in the PPEQ program utilizes ISO17025 certified methodologies for ELISA, PCR, qPCR and Next Generation Sequencing (NGS) tests to detect pathogens. Laboratory testing of potato plantlets is complemented with grow-out tests in contained greenhouse space. Other potential avenues of introducing foreign pathogens such as flower bulbs and ornamental plants are addressed by import requirements and visual inspections.

The Canadian seed potato program combines tolerances for blackleg disease with all wilts and certifies based solely on field scouting and visual inspection of plants during the growing season. The nuclear and pre-elite are the highest of eight classes of seed potatoes in the certification scheme and they have a zero tolerance level for blackleg and wilt, while the lowest class, the certified class, has a tolerance of $3 \%$ for blackleg and wilt during seasonal inspections and a $2 \%$ tolerance for the last field inspection. The intermediate classes of seed have tolerances ranging from 0.1 to $1.0 \%$. As in Europe, roguing is an acceptable practice to lower the incidence of blackleg and wilts in seed potato crops and is used by growers as a management strategy to ensure these diseases are within tolerance levels. The Canadian seed potato certification program relies on the use of pathogen-tested tissue culture for the nuclear class and the flush through concept, in which each next generation is automatically downgraded one class, to control tuber-borne diseases such as blackleg.

Other than for the seed potato certification program, CFIA does not conduct national regulatory testing or certification of stock potato production for any of the soft rotting plant pathogens. However, some of the provincial departments of agriculture carry out their own field scouting and laboratory testing and diagnosis for plant pathogenic pests, including those causing blackleg and soft rot diseases.

While not required for certification, the CFIA has laboratory capacity to test for and identify SRP. The laboratory has available immunofluorescence and ELISA protocols for identifying $P$. atrosepticum, and PCR methods for detecting and identifying SRP associated with potatoes (see Chap. 5). Some commercial laboratories in Canada that offer plant diagnostic services also have the capability to test for SRP 
but none have been approved by the certification agency to conduct these tests for domestic or international trade requirements.

\subsection{Cultivation Measures and Hygiene}

\subsubsection{Use of Clean Seed and Planting in Pathogen-Free Area}

As SRP are seed-borne pathogens, they can move during plant growth from infected plant tissue, including the mother tuber, via free water in soil to progeny tubers or through the vascular system of the plant. During (post)harvest activities, contact with infected (rotten) tubers and contaminated machinery can result in a further increase of infection rates (Ansermet et al. 2016; Czajkowski et al. 2012a). Therefore, the use of clean seed is the most important cultivation measure to control SRP populations in potato crops. This can be achieved by beginning with good hygiene in the early stages of plant material multiplication to ensure pathogen-free propagative material (Baghaee Ravari et al. 2013). This is usually achieved through the implementation of seed certification schemes (see Sect. 6.2). The efficiency of control is variable, due partly to the presence of latent infections in seed lots that can persist even in multiple consecutive generations. Prevailing environmental conditions play an important role in disease development and expression (Czajkowski et al. 2011b; Bontemps-Gallo et al. 2013; Dubois Gill et al. 2014).

In theory, cutting of seed can facilitate infections through wounds, and possibly transmit the pathogens through bacteria remaining on the device used to cut the seeds. De-sprouting of tubers at planting may also transmit the pathogen (Elphinstone and Toth 2007). Wastie et al. (1994) investigated the effect of seed tuber inoculation with $P$. atrosepticum on the development of blackleg symptoms and on yield in 15 cultivars. Tubers were planted either whole or as pieces. Inoculations reduced the mean yield per plant by $8 \%$ for whole tubers and by $12 \%$ for cut tubers, although there was no correlation between blackleg symptoms and yield loss. In the Netherlands, it is generally seen that if seed cutting is done with a cutting knife that is continuously disinfected, and freshly cut tubers are treated with talcum powder to absorb moisture, no increase in blackleg prevalence is found (Van der Wolf, Wageningen, NL, pers. comm.). Planting in potato production areas free from specific SRP is another option to avoid an increase in blackleg intensity. In these protected areas, measures should be taken to avoid the introduction of new SRP species through import of infected planting material (Lumb et al. 1986; Sławiak et al. 2009; Laurila et al. 2008; Tsror et al. 2009). It further requires intensive surveys and an effective eradication program to prevent spread of the pathogen in case of an outbreak. In countries with a socalled "Safe-Havens Scheme" the introduction of SRP from abroad are avoided but not necessarily the dissemination of pathogens regionally (Toth et al. 2011). Only disease-free micro-propagation material can be imported from outside the area, and subsequent generations should be grown on farms that cannot use seed tubers 
produced outside the scheme (Potato_Council 2009). As a result, so far D. solani has never been found on seed potatoes grown in Scottish fields, including those grown from Scottish origin seed (Saddler, SASA, Edinburgh, Scotland, unpublished results).

\subsubsection{Influence of Soil Conditions on Blackleg and Soft Rot}

Several studies have been conducted to determine the survival of SRP in soil, although results are often biased by the lack of sensitive detection methods (Pérombelon and Hyman 1989; EFSA 2013a, b). Even the most sensitive detection methods, based on enrichment and the use of DNA-amplification, have a limit of detection higher than the cell densities able to infect plant roots (EFSA 2013a, b). In addition, SRP present in a viable but not-culturable (VNBC) state in the soil will go unnoticed if detection methods reliant on culturing are used (McDougald et al. 1998). Nonetheless, studies on the survival of SRP in soil have shown that it is unlikely that these pathogens can overwinter freely for extended periods in soil in the absence of a host or plant debris. Introduction of SRP into pathogen-free soils can occur through irrigation or surface water, aerosols (Franc et al. 1984; Graham et al. 1977) or through survival in weeds or volunteers (Tsror et al. 2010), subsequently leading to infection of crops (see also Chap. 3). Soil moisture content, temperature, soil nutrient status, organic matter content and soil microbial composition all play a role in pathogen survival (Pérombelon and Hyman 1989; Moh et al. 2011; Czajkowski et al. 2011b). A high soil moisture is conducive for pathogen survival, proliferation and disease development as was found for experiments with $D$. solani in soil in which root infections occurred more easily in wet than in dry soil (Czajkowski et al. 2010). Rahman et al. (2012) confirmed that irrigation creates a moist soil environment, which favours infections by blackleg pathogens. The same is true for the development of diseases in other hosts, for example, soft rot of Zantedeschia spp. caused by Pectobacterium carotovorum is most severe when plants are under stress from low soil aeration, high temperatures or high humidity (Funnell and Mackay 1999; Wright and Burge 2000; Luzzatto et al. 2007), as is the case with soft rot of carrots (Farrar et al. 2000). Therefore, planting in well-drained soils and avoiding over-irrigation can help to reduce disease development.

\subsubsection{Effect of Plant Nutrition on Blackleg and Soft Rot}

Nutrition affects the resistance/tolerance status of the plant and/or virulence of the pathogen. Plants with an optimal nutritional status have the highest resistance to disease, while deficiency or an excess of essential elements may result in an increased susceptibility to diseases (McGovern et al. 1985; Huber et al. 2012). 
Nitrogen $(\mathrm{N})$ is the fourth most abundant element in plants and is found in various parts of the plant in different forms. $\mathrm{N}$ is a component of proteins, enzymes, hormones, phenolics and phytoalexins, which all affect disease development (Huber and Thompson 2007; Elmer and Datnoff 2014). The effect of nitrogen levels on blackleg has been explored by Graham and Harper (1966), who showed that blackleg incidence caused by $P$. atrosepticum was lower in field plots with a relatively high $\mathrm{N}$ supply (Fig. 6.1). With a low amount of $56 \mathrm{kgN} / \mathrm{ha}$, an average of $25 \%$ of blackleg was observed at the end of the growing season, while with a high amount of $224 \mathrm{~kg} \mathrm{~N} / \mathrm{ha}$ the percentage of blackleg was about $10 \%$ lower (16\%). Graham and Harper (1966) observed that there was no interaction between variety and nitrogen supply, suggesting that this tendency holds whatever the variety. Others found that a high nitrogen supply promotes blackleg. For example, Dubois Gill et al. (2014) indicated that $\mathrm{N}$ input, jointly with the content of organic matter in the soil, contributes to $9 \%$ of the variability of blackleg symptom expression in the field. High nitrogen supply also increases nitrate content in the progeny tubers (Maltas et al. 2018), which could theoretically promote the development of soft rot in the progeny tubers after harvest through a proliferation of SRP using nitrates simultaneously as a nitrogen source and an electron acceptor (Smid et al. 1993). Nevertheless, this has never been experimentally tested with potatoes. A high $\mathrm{N}$ supply may also have other negative effects on potato crops, e.g. by increasing the incidence of late blight of foliage (Bangemann et al. 2014) or reducing starch content in the progeny tubers (Maltas et al. 2018).

Calcium $(\mathrm{Ca})$ is a macronutrient improving the structural integrity of the cell membrane and cell wall components and is also involved in numerous biotic and abiotic environmental signals (Dodd et al. 2010; Lecourieux et al. 2006). The Ca content in plant tissues has been positively correlated with resistance against SRP in

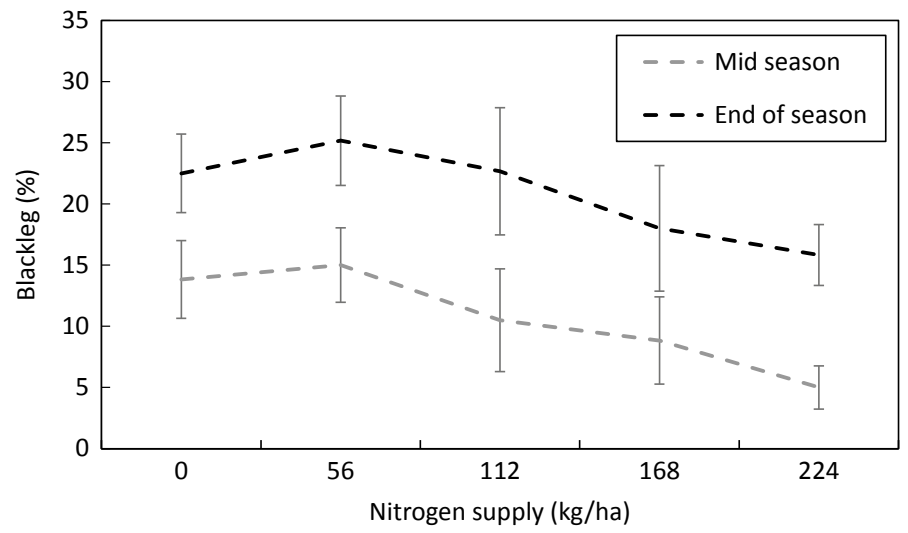

Fig. 6.1 Percentage of blackleg at two periods of the growing season corresponding to an increased nitrogen supply. The data were retrieved from Graham and Harper (1966) and is an average of three cultivars (Kerr's Pink; Majestic and Arran Consul), and the error bars show the standard error of the mean 
several studies (McGuire and Kelman 1984; da Silva Felix et al. 2017). The mode of action of $\mathrm{Ca}$ against SRP appears to be due to an interaction of $\mathrm{Ca}$ ions with cell wall pectin, which strengthens the plant cell walls and results in higher resistance to pectinolytic enzymes released by SRP that act to degrade the cell wall (White and Broadley 2003; Barras et al. 1994). Ca fertilization is known to reduce soft rot caused by SRP in Chinese cabbage (da Silva Felix et al. 2017; Park 1969), in bean (Platero and Tejerina 1976), in chicory (Schöber and Vermeulen 1999) and in potato (Ngadze et al. 2014; McGuire and Kelman 1984; Lambert 1991; Ngadze 2018b). However, field trials in Scotland by McGuire and Kelman (1984) revealed that bacterial soft rot caused by $P$. atrosepticum is negatively correlated with $\mathrm{Ca}$ concentration in tubers, and Mantsebo et al. (2014) came to the same conclusions for $P$. brasiliense after field trials planted in Zimbabwe. A study of blackleg control carried out with tubers inoculated with $P$. atrosepticum and planted in soils enriched with gypsum $\left(\mathrm{CaSO}_{4}\right)$ at a rate of up to 27 tonnes/ha, revealed a delay in the outbreaks of blackleg symptoms (Bain et al. 1996). Nevertheless, no significant difference in blackleg incidence was observed 15 weeks after planting. A more recent study using calcium nitrate as an amendment revealed that a supply of $250 \mathrm{~kg} / \mathrm{ha}(19 \% \mathrm{Ca})$ allowed an average reduction of $20 \%$ blackleg symptoms, with a maximum of $50 \%$ (Ngadze 2018a). The corresponding experiments were carried out with seed tubers inoculated with a mixture of $P$. atrosepticum, $P$. brasiliense and $D$. dadantii. In this study, the blackleg incidence in Ca enriched plots remained lower even 12 weeks after emergence (Fig. 6.2). While soil with $\mathrm{Ca}$ amendment appears to have an effect on blackleg and soft rot symptom expression, seed treatment with Ca had no clear effect on soft rot disease (Bartz and Kelman 1986) It must also be considered that Ca

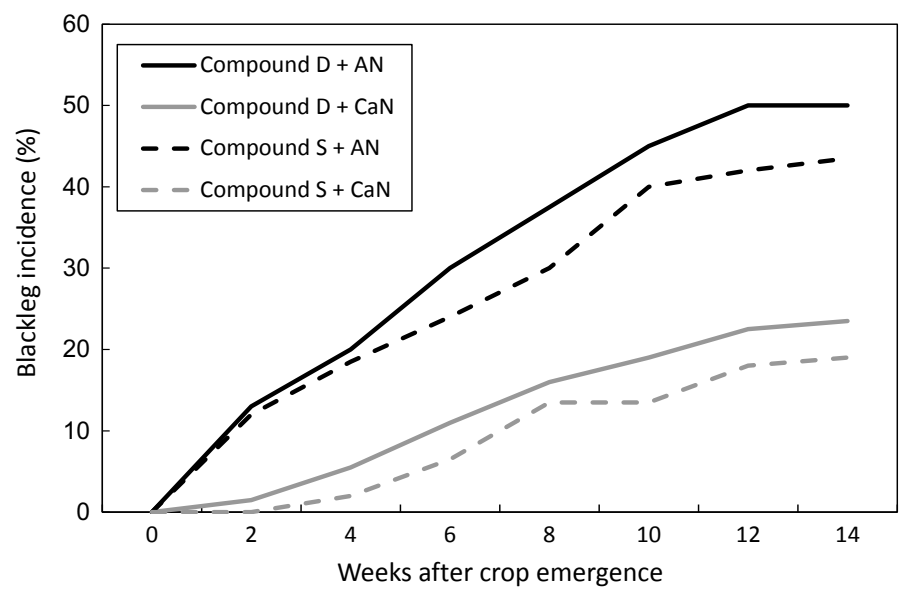

Fig. 6.2 Progression of blackleg incidence of four fertilization treatments. The treatments were: (1) compound S [7 N: $21 \mathrm{P}: 8 \mathrm{~K}]+$ ammonium nitrate [34.5\% N]; (2) compound D [7 N: $14 \mathrm{P}$ : $7 \mathrm{~K}$ ] + calcium nitrate [19 Ca: $15.5 \mathrm{~N}$ ]; (3) compound $\mathrm{S}+$ calcium nitrate and (4) compound D+ ammonium nitrate. The data presented are the average of two field experiments retrieved from Fig. 1a, b in Ngadze $(2018 \mathrm{a}, \mathrm{b})$ 
amendment can promote the development of other potato diseases such as common scab, as the content of exchangeable $\mathrm{Ca}$ in the soil favours the development of this disease (Lambert 1991; Goto 1985; Davis et al. 1974).

Higher magnesium $(\mathrm{Mg})$ content in tubers was found to correlate with a lower soft rot incidence (McGuire and Kelman 1986), as well as a lower stem rot incidence (Bain et al. 1996) but to a lesser degree than equivalent amounts of $\mathrm{Ca}$. These experimental data are in line with the results of Dubois Gill et al. (2014) indicating that Mg input can delay blackleg disease outbreaks in the field.

In conclusion, plant nutrition has an influence on soft rot and blackleg incidence. Plant nutrition also affects other diseases and is a determinant factor for potato yield and quality (Lambert et al. 2005). Several examples are given above to show that adapting fertilization may reduce blackleg and/or soft rot incidence, although this may also have detrimental effects on other diseases and on potato quality. Balancing nutrition in the potato crop is therefore an important aspect of production.

\subsubsection{Minimising the Sources of Infection (Plant Debris, Alternative Hosts and Roguing)}

When a crop is grown for marketing as seed potatoes, roguing is a key component in maintaining the health status of the crop. Roguing of blackleg diseased potato plants is recommended by the seed certification procedures. Nevertheless, the efficacy of this method in controlling the spread of SRP bacteria is controversial since it does not always ensure sanitization of the entire crop (Bonde 1950; Pérombelon 1992). In the Netherlands, the efficacy of roguing has been tested experimentally but results were inconclusive (Boomsma et al. 2012). It is expected that roguing in controlling blackleg is only effective if the entire plant is physically removed, including the mother tuber as well as the progeny tubers, and measures are taken to prevent contact of diseased tissue with other plants in the field (De Boer et al. 2012).

Volunteer plants can be a concern in potato-growing areas for various reasons: they can be a source of varietal mixtures in potato crops, pose weed control issues in other field crops and can also act as a reservoir for potato pathogens where they may impact on the phytosanitary status of seed potatoes. These volunteer plants grow from tubers remaining in the field following harvest because a significant proportion of tubers are too small to be collected by harvesters and will remain in the soil over the winter crop (Rakotonindraina et al. 2011). Nevertheless, in climates in which the top layer of soils are frozen during winter time, the survival of those volunteers is limited and clearly less than the time period from one potato crop to another in an average crop rotation system (c. 3-5 years). During this time, the volunteers would have been destroyed by frost or due to the decay of the mother tuber (Lutman 1977; Boydston et al. 2006; Cooke et al. 2011; Pérombelon 1992). Therefore, it is recommended that short crop rotations be avoided (Elphinstone and Toth 2007). When volunteers are present in the potato crop, it is fundamental to remove them from the field as soon 
as possible as they may be a source of SRP inoculum (Toth et al. 2011) but also an inoculum source for other pathogens, such as viruses or Phytophthora infestans.

Most of the weed species in temperate regions are annual plants (Simić et al. 2016) growing in spring after germination of the seed. Some of these weeds are known hosts of Pectobacterium and/or Dickeya spp., such as plants of the Amaranthaceae, Brassicaceae, Fabaceae and Poaceae families (reviewed in Ma et al. 2007). SRP can be found on weeds in potato fields (see Sect. 3.2.4). For example, P. atrosepticum was detected in $15 \%$ of the weed samples collected in two potato fields in Scotland (Avinash et al. 2013) but it is not known whether those weeds were infected from potato plants or from other sources in the potato ecosystem. It is further unknown whether potato plants can become infected via contact with contaminated weeds. Finally, debris remaining from a previous non-potato crop may present a threat to the following potato crop (Toth et al. 2006). For cropping systems using rotation, potato crops can be infected by debris of other crops that have been identified as hosts of SRP. For example, sugar beet and sunflower are known to be hosts of Pectobacterium spp., while carrot and chicory are known as hosts for both Dickeya and Pectobacterium spp. (Ma et al. 2007; Baştaş et al. 2009; De Haan and Garcia Diaz 2002). While there is no clear data on the importance of this potential source of contamination, as a precaution it is recommended that these crops do not appear in a rotation prior to potatoes.

\subsubsection{Haulm Killing Management and Harvest Management}

It is a common practice to destroy the potato crop by killing the haulm when it is still partly green and tubers are still growing, inducing the artificial maturation of the progeny tubers, especially skin setting. This haulm killing can be performed mechanically, chemically or by combining mechanical and chemical methods (Kempenaar and Struik 2007).

Pérombelon et al. (1979) showed that P. atrosepticum was present in aerosols produced during mechanical haulm destruction (haulm flailing) of potato crops presenting blackleg. The authors concluded that mechanical haulm killing in seed crops with blackleg would increase contamination and disease risk in subsequent crops. Nevertheless, the infection of the progeny tubers was not evaluated in this experiment. More recently, trials were set up in Scotland to compare the effects of mechanical haulm killing (haulm flailing) with chemical haulm killing (Diquat$0.34 \mathrm{l} / \mathrm{ha}$ ) in two potato fields heavily infected by $P$. atrosepticum (61 and $27 \%$ of blackleg) (Wale et al. 2013). In these experiments, there was no evidence that mechanical haulm killing resulted in increased contamination of the progeny tubers over the chemical (Diquat) treatment. However, this experiment was performed only twice and it may be that the risk would be higher when haulm destruction is performed in wet conditions, as bacteria could multiply in debris remaining on the soil surface after flailing of the haulm and may infect the progeny tubers underground (Burgess et al. 1994; Kastelein et al. 2020). It is also recommended that rapid haulm destruction is 
performed to reduce the exposure of the crop to potential infection (Elphinstone and Toth 2007; Toth et al. 2011).

At harvest and grading, rotting tubers must be removed rapidly from the harvester and grading machines before their disintegration and the spread of rotting tissue, as one rotting tuber is able to contaminate up to $100 \mathrm{~kg}$ of healthy tubers (Elphinstone and Pérombelon 1986; Pérombelon 2002). This precaution must be coupled with an adequate adjustment of the machines to avoid wounding of the progeny tubers that would facilitate their infection, as bacteria can survive after wound healing (Pérombelon 1992; van Vuurde and de Vries 1994). It is also recommended to harvest in dry conditions and at temperatures above $10^{\circ} \mathrm{C}$ as cold temperatures increase the potential for potatoes to shatter bruise or for fissures to occur, and thus allow the entry of pathogens such as SRP (Olsen et al. 2012; Toth et al. 2011). Harvest must be initiated after a proper skin set of the progeny tubers, as Pectobacterium spp. are unable to breach healthy tuber periderms. A well-set skin is therefore the best defence against soft rot disease in storage (Charkowski 2015) and is also a good protection against wounding. It has been shown that thorough washing and disinfection of the machinery used for planting, spraying, haulm killing and grading reduce the risk of introducing the soft rot bacteria to healthy seed lots (Pérombelon 2002; Pérombelon and Kelman 1980).

\subsubsection{Optimized Storage Conditions}

To reduce disease development and spread in storage, damage to fresh produce must be minimized at harvest and during grading. Rotting tubers should be removed before storing and packing, with graders and sorters being disinfected regularly and good hygiene maintained in the store. Washing of seed tubers or potatoes for market should be avoided unless necessary. In such cases, disinfectant is added to the wash water, and the water replaced regularly (Charkowski 2015). Numerous physical, chemical and biological treatments have been evaluated for the control of soft rot and although some have shown potential, they are either costly or require additional research for optimisation (Elphinstone et al. 2018).

SRP enter tubers through lenticels, vascular tissue and wounds. Efficient wound healing and skin set will therefore reduce the potential number of entry points for bacteria. Optimal conditions for curing of potatoes vary with cultivar and SRP present, but according to Knowles et al. (1982) wound healing at $9{ }^{\circ} \mathrm{C}$ for about 25 days was optimal to reduce rotting without compromising the physiology of the tubers.

Potatoes should be stored in well ventilated conditions at $3-4{ }^{\circ} \mathrm{C}$, as soft rot develops very slowly at temperatures below $10{ }^{\circ} \mathrm{C}$ (Kushalappa and Zulfiquar 2001; Wicks et al. 2007). Good storage facilities include both refrigeration and ventilation, with some refrigeration systems providing positive ventilation of the storeroom (Elphinstone et al. 2018). However, dead air pockets can still occur in storage facilities in which average temperature, relative humidity and ventilation are controlled. 
Such dead air pockets in piles or boxes can result in microclimates with increased temperature, thus causing condensation and lowered oxygen concentrations around tubers (Pringle and Robinson 1996) creating a favourable environment for the development of soft rot (De Boer and Kelman 1978). Proper control of temperature, relative humidity and oxygen concentration throughout storage facilities should lower tuber inoculum load and keep rotting to a minimum.

\subsection{Physical and Chemical Treatments of Seed Tubers to Control Blackleg and Soft Rot}

Seed tubers are the main route by which SRP infect potato plants to cause blackleg disease and tuber soft rot. Therefore, effective seed treatments may reduce seed decay, blackleg and aerial stem rot symptoms in the field and tuber soft rot in storage (Elphinstone and Pérombelon 1986).

Most of the available information on physical and chemical control of bacterial pathogens in potato comes from the control of Pectobacterium spp., whereas only limited information is available on the control of Dickeya spp., which has recently been reviewed (Czajkowski et al. 2011b). Physical and chemical treatments applied to seed tubers have focused on reducing SRP populations in latently infected tubers (Czajkowski et al. 2011b; Charkowski 2015). However, the inability of these treatments to fully kill the bacteria located deep in the vascular system of the tuber or in the lenticels, without negatively effecting the plant or tuber development, significantly limit their efficacy.

Physical seed treatments, such as hot water, steam, hot dry air and UV radiation are environmentally friendly and recognized as competitive to biological and chemical methods, as they may be effective against a broad range of pathogens and registration is not required (Czajkowski et al. 2011b). However, they may negatively influence tuber emergence and affect beneficial microorganisms. Hot water seed treatment for $5 \mathrm{~min}\left(\right.$ at $55^{\circ} \mathrm{C}$ ) followed by drying under forced ventilation resulted in effective blackleg control obtained in field experiments (Pérombelon et al. 1989). The use of steam treatment as an alternative to hot water treatment reduced infection of tuber periderm from 26-59\% to 1-3\% (Afek and Orenstein 2002). In Israel, on a limited scale, steam treatments are used now in practice not only to reduce damage by SRP but also by other tuber-borne diseases (Tsror, Gilat, Israel, pers. comm.). Application of hot dry air at $50{ }^{\circ} \mathrm{C}$, which dries the tubers and stimulates wound healing without interfering with tuber sprouting as much as hot water treatment, eliminated external populations of Pectobacterium spp. (Bartz and Kelman 1986). UV radiation was also reported as effective in eliminating superficial contamination of Pectobacterium spp. (Ranganna et al. 1997). Currently, these methods are not available for high throughput application and therefore are not implemented in practice (Czajkowski et al. 2011b; Charkowski 2015). 
A wide range of chemical compounds has been tested to reduce infection by SRP on or inside tubers. Most compounds contain antibiotics (mainly streptomycin and its derivatives), inorganic and organic salts or combinations of these compounds (reviewed by Czajkowski et al. 2011b). However, antibiotics are not used in potato production because of the risks of introducing resistance to bacterial pathogens of humans or animals. As an alternative to antibiotics, a wide range of potential bactericides has been tested (Czajkowski et al. 2011b). Organic compounds such as hydroxyquinoline and 5-nitro-8-hydroxyquinoline were effective for control of soft rot in wounded potato tubers (Harris 1979). Inorganic and organic salts, including aluminium acetate, sodium metabisulphate, propyl paraben, sodium benzoate, potassium sorbate, calcium propionate, sodium hypochloride, sodium bicarbonate, aluminium chloride and copper sulphate could inhibit the growth of $P$. carotovorum and $P$. atrosepticum in vitro (Mills and Hurta 2006). The ability of bacteriocides and sanitizers such as ethanol, sodium hypochlorite, copper sulphate, peracetic acid, hydrogen peroxide, benzoic acid, tri sodium phosphate and caffeine to reduce SRP concentrations was recently evaluated (Czajkowski et al. 2013). However, in greenhouse experiments, treatments with all disinfectants except hydrogen peroxide and caffeine resulted in high phytotoxicity, reducing sprouting of tubers by 10-100\% (Czajkowski et al. 2013). Sodium hypochlorite and benzoic acid applied to inoculated tubers prevented development of soft rot symptoms on tubers under conditions conducive for soft rot (Czajkowski et al. 2013). Essential oils have been considered as an alternative to sustainable management of pests due to their recognized antimicrobial activity. Among the tested oils, essential oil of thyme, with thymol as the main constituent (57\%), showed the highest antibacterial activity against $P$. carotovorum (Minimum Inhibitory Concentration $=0.2 \%$ ), whereas, anise and white basil essential oils showed relatively weak activity (Rojas et al. 2014). Antibacterial activity of silver nanoparticles (AgNPs) stabilized by pectin (PEC) or sodium dodecyl sulfate (SDS) tested against SRP demonstrated bactericidal activity, with minimum inhibitory concentrations of 5.5 and $0.75-3 \mathrm{mg} \mathrm{L}^{-1}$, respectively (Dzimitrowicz et al. 2018). The application of these compounds for tuber treatments should be further investigated and evaluated as part of a blackleg and soft rot management strategy (Dzimitrowicz et al. 2018). SRP can infect the haulms of potato plants during the growing season. Foliar sprays with copper-containing compounds contribute to the control of bacterial stem rot by protecting wound sites from infection (Johnson et al. 2011) but are undesirable from an environmental point of view.

The potential of antimicrobial peptides from animal or plant origin for control of SRP has also been explored as an alternative to the use of antibiotics. GonzálezRodríguez et al. (2005) showed that the antimicrobial peptide melittin at relative low concentrations had an inhibitory effect against different strains of SRP, although D. chrysanthemi was moderately resistant. Another study assessed the antimicrobial activity of a material hybrid (HDL/BAM) that associated the $\mathrm{ZnAl}$ matrix with anions of ceftriaxone as a biologically active molecule (BAM). The matrix is capable of releasing BAM against $P$. carotovorum, a pathogen rarely responsible for blackleg 
disease but often for post-harvest losses. The matrix had no biocidal activity, but the hybrid material was bactericidal (Morales-Irigoyen et al. 2018).

To conclude, none of these treatments enable the eradication of SRP post infection. Nevertheless, application of these treatments may help to reduce the incidence of blackleg and may be used to avoid infections of plant materials by the SRP in a preventive way.

\subsection{Biological Control of Pectobacterium and Dickeya spp.}

The current European policy to reduce the use of synthetic chemical plant protection agents and simultaneously ensure consistent quality and quantity of crops creates a large demand for environmentally friendly bio-formulations and bio-products, such as microbial agents. Considering the on-going reinforcement of the integrated plant protection policy in Europe (Directive 2009/128/EC of the European Parliament and of the Council), the new strategies require alternative plant protection tools to chemical agents, such as natural compounds and microorganisms.

An alternative strategy for protecting plants during their growth, as well as under post-harvest storage conditions, might be through the application of a Biological Control Agent (BCA) (Jafra et al. 2009; Kastelein et al. 2018; Kloepper 1983; Krzyzanowska et al. 2012a), either alone or combined with physical and/or chemical treatments as part of so-called Integrated Pest Management (IPM). The activity of BCAs against SRP can result from different mechanisms: (i) the production of antimicrobial compounds (Bakker et al. 2002; Ongena et al. 2005; Krzyżanowska et al. 2016); (ii) interference in the quorum sensing (QS) mechanism (Czajkowski and Jafra 2009; Grandclément et al. 2016); (iii) supporting colonization of the niches occupied by SRP by competition for nutrients with saprophytic microorganisms (Compant et al. 2010); and/or (iv) activation of a natural plant defence system by induced systemic resistance (ISR) (Bakker et al. 2007; Ongena et al. 2007). As the current state-of-the-art for potential BCAs was described recently by (Czajkowski et al. 2011b), here we describe only the more recent advances in the field (since 2011).

\subsubsection{Selection of BCA Strains}

It is already well accepted that bacteria from the plant rhizosphere or plant endophytes may successfully protect plant tissues against SRP. The majority of this research was focused on the selection of strains inhibiting the growth of these pathogens via production of antimicrobial compounds, competition for nutrient and iron (Gerayeli et al. 2018; Krzyżanowska et al. 2016; Des Essarts et al. 2016) or by attenuation of the activity of the pathogen via interference with the QS mechanism (Czajkowski et al. 2011a; Barbey et al. 2013; Garge and Nerurkar 2017; Krzyzanowska et al. 2012b). 
These isolates were mainly classified to the genera Bacillus, Pseudomonas and Serratia (Beneduzi et al. 2012; Matilla and Krell 2018; Jafra et al. 2009; Ossowicki et al. 2017).

The ability to chelate iron highly enhances microbial competition in the plant environment (Expert et al. 1996), hence the producers of strong siderophores may also contribute to the plant tissue protection towards soft rot pathogens. Numerous bacterial strains have proved their antagonistic potential towards SRP in artificial growth media, as well as in plant tissues under laboratory conditions. However, few were tested under greenhouse/field conditions and none have been developed into a commercial product specifically for use against SRP, although tests are ongoing.

Frequently, the efficacy of a BCA is based on the expression of various mechanisms. For example, Serratia plymuthica strain A30 was selected as an antibiotic producer that inhibits the growth of D. solani (Czajkowski et al. 2012b) but it was also able to induce systemic resistance in tissue-culture grown potato plants, and by doing this also attenuated the growth of D. solani in planta (Czajkowski et al. 2015). Recently, Gerayeli et al. (2018) characterized several Bacillus spp., i.e. B. subtilis IrB2, B. pumilus IrB8, B. amyloliquefaciens $\operatorname{IrB} 12$, and B. thuringiensis $\operatorname{IrB} 14$, which showed antagonistic potential towards $P$. brasiliense. These strains were also able to induce a systemic response in potato tuber tissue and two of them, viz. B. subtilis IrB2 and B. thuringiensis IrB14, were able to interfere with the QS regulation of the pathogen. The latter is a common phenomenon in Bacillus spp. due to the ability of these bacteria to enzymatically degrade QS signal molecules (Dong et al. 2004; Krzyzanowska et al. 2012b; Garge and Nerurkar 2017). Another biological control agent Pseudomonas donghuensis $\mathrm{P} 482$ was found to produce a strong non-fluorescent siderophore, which might contribute to the antibacterial activity of this strain towards SRP as well as towards other plant pathogenic bacteria (Krzyżanowska et al. 2016).

\subsubsection{Greenhouse and Field Experiments}

Limited studies have been performed on the control of SRP using BCAs under greenhouse conditions (Czajkowski et al. 2012b; Des Essarts et al. 2016; Li et al. 2018), and there has only been one published field scale experiment (Tsuda et al. 2016). Czajkowski et al. (2012b) selected a set of antagonists against D. solani IPO2222. Firstly, potential antagonistic bacteria were isolated from the rotting potato tuber. In total 650 isolates were screened for antagonistic activity towards D. solani in an in vitro assay followed by a tissue protection test on potato tuber slices. Where possible, antagonistic isolates were phenotyped and their taxonomic classification determined. This strategy resulted in the selection of twelve isolates for greenhouse experiments to verify their effectiveness in protecting potato plants against $D$. solani. The first greenhouse trial resulted in the selection of four candidates for a second 
greenhouse experiment: Bacillus simplex A19, Serratia plymuthica A30, Obesumbacterium proteus S9 and Pseudomonas fulva S23. From these isolates, the endophyte $S$. plymuthica A30 proved to be efficient in blackleg disease control in greenhouse experiments under disease-inducing conditions. S. plymuthica A30 produces antibiotics, biosurfactants and plant growth promoting auxins. Due to its motility and capacity to colonize, it protected potato plants by reducing blackleg symptoms caused by $D$. solani by $100 \%$ and colonization of the stems by $97 \%$. A subsequent postharvest treatment of seed tubers with $\mathrm{A} 30$ resulted in a reduction of soft rot during storage, as well as reduced blackleg in the following growing season (Hadizadeh et al. 2019). Various isolates of Serratia plymuthica have already shown antagonistic capacity towards fungal pathogens, with strain S. plymuthica HRO-C48 included in the commercial biocontrol product Rhizostar® (EU Patent 98,124,694.5) developed against Verticillum wilt.

Another study on the isolation, screening and selection of antagonistic bacteria towards strains of Dickeya and Pectobacterium spp. was performed by Des Essarts et al. (2016). More than 10, 000 bacteria originating from rhizosphere soils, asymptomatic potato tuber tissue and blackleg and soft rot diseased potato tissue were successively screened. In the first screening more than 240 isolates were selected as capable of inhibiting growth of $D$. dianthicola and $P$. atrosepticum. Subsequent screenings resulted in selection of six isolates, which showed the highest protection of potato tissue after infection by pathogens. The isolates classified as Bacillus simplex BA2H3 and Pseudomonas brassicacearum PA1G7 and PP1-210F were effective towards $P$. atrosepticum induced symptoms, while Pseudomonas fluorescens PA3G8 and PA4C2 and $P$. putida PA14H7 were highly antagonistic towards $D$. dianthicola spp. The last three strains were further tested in four independent greenhouse experiments to establish their potential for protecting potato plants artificially infected with D. dianthicola RNS04.9. The level of reduction varied per location (Brittany or NordPas-de-Calais) and per experiment, but the best reduction of disease symptoms and transmission of the pathogens to progeny tubers was observed when the three strains were applied together in the mixture. In silico analysis of the genome sequences of the $P$. fluorescens PA3G8 and PA4C2 and P. putida PA14H7 strains revealed the presence of genes encoding biosynthesis of bacteriocins, adhesins important for biofilm formation, as well as different types of siderophores. All these potential features may be involved in antagonistic activity by the selected strains.

\subsubsection{Bacteriophages}

The idea of using lytic bacteriophages (phages) to control plant pathogenic bacteria was introduced as early as in 1920s (Mallmann and Hemstreet 1924), less than ten years after phages were discovered and described for the first time. In 1925, it was demonstrated that lytic viruses were able to provide protection against $P$. atrosepticum inoculated into potato tuber tissue (Coons and Kotila 1925). Between 1980 and 2010s, several proof-of-principle experiments were carried out to test whether lytic phages 
could be used against different SRP and in several different scenarios (Balogh et al. 2010; Czajkowski et al. 2014; Eayre et al. 1995). Most of these studies were, however, restricted to laboratory experiments and only in a few cased was the usefulness under field conditions tested. In a field experiment in Belgium, tuber treatment resulted in a slight yield increase but not in a significant reduction of the percentage of infected progeny tubers (Adriaenssens et al. 2012). Currently, it has not yet been agreed how to apply SRP phages for effective control of blackleg in the field. However, for control of soft rot in the potato packing industry, the commercial product Biolyse ${ }^{\circledR}$ is available from APS Biocontrol Ltd. in Scotland, UK (https://www.apsbiocontrol. $\mathrm{com} /$ ).

\subsubsection{Conclusions and Perspectives}

The number of publications presenting new potential biocontrol strains against SRP is growing. However, there is still the need to move laboratory, glasshouse and limited field studies into commercial products that can effectively protect plants against diseases caused by SRP. So far, the only commercial biocontrol product based on a non-pathogenic strain of $P$. carotovorum has been developed in Japan for protection of vegetable, cyclamen and potato tuber against soft rot disease. It is available on the market as BIOKEEPER ${ }^{\circledR}$ (Central Glass Co., Ltd., Tokyo, Japan).

It is expected that using a mixture of antagonists that have different modes of action will increase the potential of BCA for plant protection compared to the use of individual species. Antagonistic strains in a mixture may also interact with each other, possibly resulting in an increased synthesis of compounds involved in the control of the pathogens (Des Essarts et al. 2016; Tyc et al. 2014).

\subsection{Breeding Potato for Resistance}

Information on breeding of potato for resistance has been summarized and extensively reviewed previously (Czajkowski et al. 2011b; Lebecka 2017). In this chapter, therefore, we focus on information not previously discussed, although overlap is unavoidable for a more comprehensive overview. Consecutively, the susceptibility of cultivars to SRP, bioassays to test for resistance, attempts to breed for resistance, mechanisms of resistance and the biotechnology approach will be examined.

\subsubsection{Susceptibility in Commercial Cultivars}

Modern potato varieties have a narrow genetic base and are mainly derived from the Chilean Solanum tuberosum Group (Gp) Tuberosum and with contributions from 
Gp Andigena (Pavek and Corsini 2001). This may have resulted in lack of immunity against SRP in commercial cultivars, although they largely vary in their susceptibility.

In field studies in Switzerland in 2014, in which twenty commercial cultivars were tested, large differences were observed in their susceptibility against blackleg symptoms (Dupuis, Agroscope, Switzerland, unpublished results). Tubers were submerged in a suspension of $D$. dianthicola before planting and scored for the development of blackleg. The cultivars with the lowest disease incidences were Markies $(0.5 \%)$, Panda (1.5\%) and Desiree (2\%) and with the highest incidences were Agria (23\%), Kondor (24\%) and Agata (30\%).

There is also a considerable variation in the susceptibility of potato varieties for tuber soft rot (Chung et al. 2013; Pasco et al. 2006; Tzeng et al. 1990). In France, in total 93 cultivars developed between 1935 and 1987, and 157 cultivars developed between 1987 and 1997 were tested (Pasco et al. 2006). A wide variation in mean rot volumes was found six days after inoculation of cut tubers. Studies in the USA also showed significant differences in the susceptibility of soft rot for 14 cultivars grown on a loamy sandy soil or a silt loam and assayed by subsequent inoculation of tubers with $P$. atrosepticum and incubation in a mist chamber (Tzeng et al. 1990). The ranking of resistance was similar for both soils. Susceptibility was correlated with a combination of Ca content and dry matter in the tubers. In other studies in the USA, 65 potato clones cultivated in the same field were tested for tuber maceration by $P$. carotovorum directly after harvest and at two-month intervals (Chung et al. 2013). During six-month of storage, significant differences in susceptibility were found between clones. The cultivars Freedom Russet, Anett and Alaska Red Eye were most resistant. The susceptibility for soft rot did not change during the 6 months of storage.

\subsubsection{Testing for Resistance}

To test for blackleg resistance, inoculation of seed tubers by vacuum-infiltration and scoring for disease development is preferred, as it mimics the natural way of tuber infection (Allefs et al. 1995). This way of testing, however, is costly in terms of time and space and is only applicable in an advanced stage of selection. Other testing protocols, including testing for tissue maceration after inoculation of tubers, stems or etiolated sprouts do not correlate well with susceptibility for blackleg (Allefs et al. 1996), although it may correlate with susceptibility for soft rot during storage. Recently, a cost-effective system was developed to quantify blackleg symptoms on the shoots of in vitro potato plants (Burra et al. 2015) and good consistency in infection between in vitro-based screening and existing greenhouse assays was found.

There remains a need for cost-effective, high throughput bioassays that can predict field resistance against diseases caused by SRP. The assays would need to test for multiple features of a potato plant that may limit introduction, colonization, population growth of the pathogen, as well as symptom development. This may be a single assay, such as the field test with vacuum-infiltrated seed tubers but also multiple 
ones testing for introductions via tubers, roots or/and haulms, resistance against tuber soft rot, transmission from seed to stem, for stem soft rot, haulm infections and transmission from stem to stolon and progeny tubers.

\subsubsection{Breeding for Resistance}

Breeding for resistance is hampered by the (quantitative) polygenic nature of resistance against SRP (Zimnoch Guzowska et al. 2000), the absence of an adequate technique to test for resistance, and possibly by the limited genetic diversity in the material used in breeding programs (Tzeng et al. 1990). Moreover, the susceptibility, expressed as the disease prevalence, is dependent on the aggressiveness of the bacterial strain tested, the physiology of the plant material, e.g. tuber size and maturity (Marquez-Villavicencio et al. 2011), and by various environmental factors including evapotranspiration and soil moisture (Gill et al. 2014). Unfortunately, results from tests in breeding programs with a released cultivar often do not coincide with the blackleg incidences found in practice (Kooman, NAK, Emmeloord, NL, pers. comm.). In addition, resistance for blackleg and for tuber soft rot are often not correlated (Pérombelon and Salmond 1995).

Breeding for resistance is also slow because commercial cultivars are tetraploids (Jansky 2000). Breeding strategies and bioassays need to be further developed to utilize the gene pool effectively for the generation of blackleg resistance cultivars. Nevertheless, resistance of wild relatives of potato with a high level of tuber and foliar resistance to $P$. atrosepticum has been introduced into a $S$. tuberosum line by inter-crossings with Solanum chacoense and $S$. yungasense (Zimnoch Guzowska et al. 2000). The F1 hybrid population was used to locate quantitative trait loci for resistance, which allowed complex inheritance of pathogen resistance to be studied. QTLs for tuber resistance and leaf resistance were located on 10 different chromosomes, although the contributions of the QTLs to leaf resistance were not well reproducible.

Similarly, resistance against tuber soft rot caused by P. atrosepticum was derived in $35 \%$ of the progeny of $4 x-2 x$ crosses between tetraploid potato lines and diploid hybrids having genetic material in their origin from $S$. tuberosum, $S$. chacoense, $S$. yungasese, S. phureja, S. gourlayi and S. demissum (Lebecka et al. 2005). From the 1425 tetraploid clones, $11 \%$ showed a good tuber appearance, yield and weight.

A molecular marker-assisted introgression was also successfully used to introduce resistance present in the tuber bearing $S$. commersonii against $P$. carotovorum into the cultivated $S$. tuberosum gene pool (Barone et al. 2001). S. commersonii is an interesting species as it also carries several useful traits including resistance to abiotic stresses, bacterial wilt, Potato Virus Y and a high capacity for cold acclimation. The interspecific barriers between the two species were overcome using a breeding scheme involving ploidy and Endosperm Balance Number manipulations (EBN). Back crossings (BC) with cultivated $S$. tuberosum resulted in a mean value of $S$. commersonii-specific RAPD or AFLP markers of ca. $92 \%$ in $\mathrm{BC} 1,75 \%$ in $\mathrm{BC} 2$ 
and $38 \%$ in $\mathrm{BC} 3$. Five resistant genotypes were found in the $\mathrm{BC} 3$, which largely resembled the $S$. tuberosum type, including a relatively low level of glycoalkaloids (Carputo et al. 2003).

Using a leaf petiole test, stem rot resistance was found against $P$. atrosepticum in a high percentage of the accessions of S. boliviense (31\%), S. chacoense (50\%), $S$. sancta-rosae (67\%), whereas most accessions of $S$. canasense, $S$. tarijense and $S$. spegazzinii were susceptible (Bains Piara et al. 1999). A petiole assay was also used to test 532 genotypes from 340 accessions comprising most known potato species, for tolerance against $P$. parmentieri, $P$. carotovorum and D. solani (Rietman et al. 2014). Under stringent test conditions, four genotypes belonging to Yungasensa subclades, including S. chacoense, were considered tolerant against Pectobacterium spp., from which only one was also tolerant against $D$. solani. Most of the tested species are diploids, which facilitate the generation of introgressions with $S$. tuberosum. The authors found an association between the susceptibility of a genotype against SRP and its origin. In particular, genotypes from a geographic region with a high soil humidity seem to be less susceptible. This contradicts information previously published by Spooner et al. (2009) who, in an evaluation of literature data, did not find an association between susceptibility of germplasm for blackleg causing agents and host taxonomy or climatic variables.

\subsubsection{Resistance Mechanisms}

Resistance to SRP has been found to correlate with the degree of methyl esterification of pectin present in the cell wall and was expressed even under anaerobic conditions (McMillan et al. 1993). Clones derived from a somatic fusion between S. brevidens, a non-tuber producing genotype with a high degree of pectin esterification, and $S$. tuberosum subsp. tuberosum were backcrossed with commercial cultivars resulting in a progeny segregated into resistant clones with a high level of methylation and susceptible clones with a low level of methylation (Pérombelon 1992). A high methyl esterification, however, negatively affects the cooked potato tuber texture, which may have affected the application of resistance based on this trait in practice (Stewart et al. 2010).

Various other traits were identified which determine the susceptibility of potato for SRP. A correlation was identified between susceptibility of tuber soft rot for 18 tested cultivars and the activity of polyphenol oxidase (PPO), peroxidase (POD), phenylalanine ammonia lyase (PAL), chlorogenic acid and total soluble phenols $8 \mathrm{~h}$ after cutting of tubers (Ngadze et al. 2011). The results may be used in selection programs for tolerant cultivars, while the identification of the genetic basis may allow the selection of genetic markers. In other research, tolerance to blackleg has also been found to be associated with the jasmonic (JA) and salicylic pathways (SA) (Burra et al. 2015). JA insensitive and SA deficient transgenic lines were more susceptible to blackleg than the non-transgenic control plants. It was further shown that a JA marker 
(lipoxygenase) and a SA (PR1) marker were induced in potato plants infected with D. solani (see Sect. 4.3.3).

The level of resistance in commercial cultivars may be strengthened using somaclonal variation or using resistance. Somaclonal variants of Russet Burbank variety, initially generated against Streptomyces spp. causing common scab, were tested for their resistance against the tuber soft rot pathogens $P$. atrosepticum and $P$. carotovorum (Thangavel et al. 2014). Some clones displayed a significant decrease in disease severity (percentage of rotted tissue) compared to the parental line, indicating that somaclonal variation may contribute to tuber resistance.

\subsubsection{Biotechnology Approaches}

The availability of plant genome sequences and efficient transformation systems have largely supported the generation of transgenic lines. Most plants engineered for resistance against SRP are transformed with antimicrobial peptides and proteins but there are also examples of transgenic plants producing enzymes inducing a resistance response, quenching the signal transduction of bacteria or increasing the level of antimicrobial metabolites.

\subsubsection{Antimicrobial Peptides}

Full resistance in potato against $P$. atrosepticum was derived in transgenic potato plants overexpressing the potato gibberellin Stimulated-Like 2 (GLS2), an antimicrobial peptide (Mohan et al. 2013). In glasshouse experiments, transgenic plants overexpressing the peptide showed no symptom development, whereas in the non-transgenic lines $93 \%$ of the plants displayed blackleg symptoms. Similarly, the expression of magainin, an antimicrobial peptide originally identified from the clawed frog Xenopus laevis, in potato plants resulted in an increased level of soft rot tuber resistance. Magainin interacts with the lipid A of the bacterial cell membrane resulting in the septic shock syndrome (Fukuoka et al. 2008). In three consecutive experiments, progeny tubers harvested from transgenic plants displayed a lower susceptibility for soft rot caused by P. atrosepticum (Barrell and Conner 2009). Transgenic potato plants expressing high levels of attacin or cecropin, antimicrobial peptides found in the cecropia moth, exhibited an increased resistance against SRP compared with the untransformed control. Resistance was revealed by a reduced severity of blackleg or soft rot symptoms (Arce et al. 1999). Transgenic potato plants have also been generated by stacking antimicrobial genes (Rivero et al. 2012). Plants were transformed with genes encoding (i) osmotin, a stress responsive antifungal protein from tobacco, belonging to the pathogenesis-related (PR)-5 family, (ii) dermaseptins, belonging to a superfamily of antimicrobial host defense peptides that are made in the skin of Hylidae frogs and (iii) a lysozyme from the red junglefowl. In particular, the expression of dermaseptin and lysozyme contributed to the resistance of plants against $P$. 
carotovorum. Stacking of the genes also resulted in resistance against Streptomyces scabies, Phytophthora infestans, Rhizoctonia solani and Fusarium solani.

\subsubsection{Quorum Quenching}

Another approach to introduce resistance is by interfering with the quorum sensing mechanism of SRP. Pectobacterium spp. sense their population density using a communication system based on signal molecules called acyl-homoserine lactones (AHLs) and receptor proteins that sense the concentration of AHLs in the environment. This communication system is vital for the expression of virulence factors, including the production of cell-wall degrading enzymes but can be disrupted using enzymes called lactonases that break down these signalling molecules (Mahmoudi et al. 2013; Dong Yi et al. 2000; Toth et al. 2004). Tobacco plants expressing a lactonase from Bacillus sp. were found to hydrolyse AHLs and enhance resistance to $P$. carotovorum (Dong Yi et al. 2001). For Dickeya spp., AHLs do not seem to play a pivotal role in the cell-dependent control of virulence genes (Nasser et al. 1998; Mehdbi-Hajri et al. 2011) but are instead under the regulation of the Vfm quorum sensing system (Nasser et al. 2013). Consequently, plants expressing lactonases may not be resistant against Dickeya spp.

As far as is known, none of the plants produced biotechnologically plants have been tested under anaerobic conditions, which will impair the resistance mechanism of the plant. Due to public concern on human health and environmental risks, so far only a limited number of transgenic potato lines have been released for commercialization (Hameed et al. 2018) but none with a resistance against SRP.

\subsubsection{Production of Cell Wall Degrading Enzymes}

Engineered potato plants expressing pectate lyases strongly induced the transcription of the plant defence related gene that encodes phenylalanine ammonia-lyase (PAL) via the degradation of unsaturated oligogalacturonates, resulting in resistance to infection by P. carotovorum (Wegener 2002, Wegener et al. 1996).

\subsubsection{Other Compounds}

Increased resistance to tuber soft rot caused by $P$. carotovorum was found after increasing the level of anthocyanin 5-O-glucosyltransferase (5-UGT) in potato tubers (Lorenc-Kukuła et al. 2005). In these tubers a significant increase in anthocyan compounds and starch, and a decrease in sugar content, was found. It remains unclear which of these changes was responsible for the decreased susceptibility to the pathogen. 


\subsubsection{New Breeding Technologies}

New breeding technologies, such as transcription activator-like effector nucleases (TALENs) and clustered regularly interspaced palindromic repeats/CRISPRassociated 9 (CRISPR/Cas9), are being used to generate potato lines with resistance to potato pathogens in a more targeted approach (Hameed et al. 2018). CRISPR/Cas9 has been used to engineering resistance against plant pathogenic bacteria in other crops (Jia et al. 2017) and the expectations are high. Nevertheless, the commercial success will largely depend on the public and government acceptance of crops derived in this way. Possibly a cisgenic approach, which involves the genetic modification of a recipient plant with a natural gene from a crossable sexually compatible plant, rather than a transgenic approach, used in the early days of biotechnology, may be helpful to overcome objections against the use of such crops (Schouten et al. 2006).

\subsubsection{Concluding Remarks}

Although resistance in wild Solanum spp. have been found, no genes have so far been identified that are useful to confer resistance in commercial potato varieties against SRP. Nevertheless, the increasing availability of genome data, in combination with new breeding technologies such as TALENs and CRISPR/CAS 9, may lead us to a break-through.

Another new development that may support the management of blackleg and soft rot diseases is the use of true potato seed (TPS), collected from the berries of potato plants. To produce TPS, homozygous parental diploid lines are crossed to obtain F1 hybrid cultivars, from which the true seeds are harvested (Lindhout et al. 2011). Using TPS, the risks for tuber-borne diseases, including bacterial and viral diseases, are largely avoided. TPS are small compared with tubers thus reducing costs of and negative impact on quality during transportation. TPS are particularly important for farmers in countries with a high temperature and limited cooling facilities in storage, as the TPS require considerably less storage space and are much less likely to develop diseases. However, true seeds demand a higher temperature to establish seed and potato production requires a longer growing season. Till recently, TPS technology resulted in genotypes with a lack of seedling vigour and a lack of uniform stand of the seedlings but the quality is improving rapidly. The first TPS cultivar (Oliver F1) was introduced commercially in 2019 by Bejo Seeds but more companies are now developing TPS cultivars.

\subsection{Disease Management in Other Crops}

SRP cause economically important losses in crops other than potato, including several vegetables and ornamentals (see Table 3.1). Since the economic losses caused by 
SRP in these crops is less than in potato, disease management is less well developed. However, due to severe outbreaks between 1990 and 2000, disease management strategies were developed for chicory and ornamentals. For example, losses caused by these bacteria in the Netherlands were fivefold higher in 2007 than in 2002, reaching 15 million euro for bulb flowers and up to $50 \%$ losses (with $90 \%$ of infected roots) in chicory production (Le Hingrat et al. 2012).

\subsubsection{Chicory}

In addition to Pseudomonas spp., the causal agents of soft rot in witloof chicory (Cichorium intybus) have been identified as both Pectobacterium and Dickeya spp. (Bouvard 1987; Vantomme et al. 1989; Le Guern et al. 1992; Samson et al. 2005; see Table 3.1).

Soft rot symptoms may occur during the three phases of production: open field root growth, root storage and forcing of the white head from mature roots. In the field, soft rot is only rarely observed, which seldom hinders root harvest (Bouvard 1987). The more critical phase for soft rot development is during head forcing, which has become a more significant problem since the introduction of hydroponic systems for this stage of the process, which uses circulating nutrient solutions. In these systems, losses of $50 \%$ or more total production regularly occur when susceptible cultivars were used (Vantomme et al. 1989; Le Guern et al. 1992).

Disease management may be applied either during root growth in the field or during chicory head forcing. In the field, controlling nitrogen fertilization may help to lower chicory head soft rot incidence. Indeed, an high nitrogen content in roots enhances chicory head susceptibility to soft rot caused by SRP, and nitrogen provided during root production in the field is positively correlated with the amount of the nitrogen content in the roots (Schöber and Vermeulen 1999). Breeding programs have included selection for soft rot tolerance, and current chicory varieties harbour a large range of tolerance to soft rot (Schöber and Vermeulen 1999). Such tolerance is often linked to nitrogen metabolism and the effect of nitrogen fertilisation varies from one variety to another. Some varieties remain tolerant whatever the nitrogen status, while others become more susceptible to soft rot in high nitrogen conditions (Laville and Benigni 1997).

A good prophylactic measure also consists of minimizing physical injuries to roots, e.g. by root harvesting when the soil is not too dry, to limit wounding that may constitute entry sites for the bacteria. As in potato, treatments with copper or calcium also provide some protection against soft rot during forcing. Both products may be applied during pulverisation of root crowns before forcing (removing mature roots to a warm, dark place in order to coax them into rapid and early growth). Copper derivatives may also be supplied a few days before root harvesting in the field, while calcium may be provided by root immersion in a calcium chloride solution just after root harvest (Schöber and Vermeulen 1999). During forcing, only physical treatments for disease management have been proposed, such as reducing the incubation 
temperature to $17-19^{\circ} \mathrm{C}$ or decontaminating the nutrient solution used in hydroponic cultures with UV light (Bouvard 1987; Marc Benigni, Association des Producteurs d'Endives, France, pers. comm.).

\subsubsection{Chinese Cabbage}

Bacterial soft rot is one of the most destructive diseases in Chinese cabbage (Brassica rapa (syn. campestris) subsp. pekinensis) (Ren et al. 2001). As with potato, chicory and other crops, disease expression is strongly favoured by a high temperature and humidity. Disease management is based on crop rotation, hygiene and cultivation measures including the use of raised beds, optimized sowing date (Fritz and Honma 1987) and the use of less susceptible cultivars (Ren et al. 2001). Studies showed that tolerance to soft rot can be conferred in Chinese cabbage by expression of $N$ acyl-homoserine lactonase (AHL-lactonase) via transformation of plants with the aii gene (AHL-lactonase gene from Bacillus sp. GH02) fused to the PinII signal peptide, protease inhibitor II from potato (Vanjildorj et al. 2009). Similarly, a reduced susceptibility was found after transformation with a gene (BAAl) encoding bromelain, a proteolytic enzyme from pineapple trees (Jung et al. 2008). Finally, transformation of plants with a gene encoding the rice leucine-rich repeat protein (OsLRP) conferred resistance to soft rot in Chinese cabbage (Park et al. 2012).

For the biocontrol of $P$. carotovorum in Chinese cabbage, Lactic Acid Bacteria (LAB) were selected from Japanese traditional fermented foods (Tsuda et al. 2016). Interestingly, LAB isolates produce bacteriocins but they may also influence the microenvironment of infection due to the production of organic acid and hydrogen peroxide and decrease in $\mathrm{pH}$ that, in turn, can have an effect on the pathogen's growth and development. More than 1160 isolates of LAB were screened in a leaf disk assay. Further analysis led to selection of isolates SHH15 and SOK04 for further field experiments. The effectiveness of these two isolates was compared in field trials with a non-pathogenic strain of $P$. carotovorum, re-isolated from the commercial product BIOKEEPER $®$. The isolate SOK04 significantly reduced disease symptoms on Chinese cabbage and was even more effective than the non-pathogenic $P$. carotovorum strain. A further study revealed that SOK04 is a mixture of two different isolates presented by big yellow colonies (BY) and small white (SW) colonies. Both type-isolates were tested in field experiments carried out independently in two seasons. BY, characterized as Lactobacillus plantarum, was effective in all field trials. BY could only establish a stable population on wounded leaves and could not persist on the healthy ones. It prevented pathogen colonization of the damaged plant or their penetration into vascular tissues. LABs are considered as BCA with a high potential for development into commercial products. They are associated with fermented foods and generally recognized as safe, with many of them being considered as probiotics and may be well accepted by the consumers. 


\subsubsection{Soft Rot in Ornamental Horticulture}

The annual global value of the flower bulb industry exceeds a billion US\$ without orchids (Benschop et al. 2010). However, it is difficult to provide the economic figures for soft rot losses in this industry because of its diverse nature and lack of data. For example, the bulb industry includes more than 800 different genera (De Hertogh et al. 2013) but is dominated by about 10 genera with thousands of cultivars, many of which have been reported as hosts for Pectobacterium or Dickeya spp. (Byther and Chastagner 1993; Van Doorn et al. 2011). For some hosts, the difference in susceptibility between cultivars has been studied in detail, e.g. the white flower Zantedeschia aethiopica cultivar is more resistant to soft rot than coloured species (Snijder and van Tuyl 2002). Environmental conditions largely influence the occurrence of soft rot in ornamental plants. For example, disease in Zantedeschia spp. caused by $P$. carotovorum is most severe when plants are under stress from low soil aeration, high temperature or high humidity (Funnell and Mackay 1999; Wright and Burge 2000; Luzzatto et al. 2007).

The last group of ornamental hosts impacted by soft rot are orchids. The most popular are Cattleya, Cymbidium, Dendrobium, Oncidium and Phalaenopsis, with hundreds of hybrids in trade and the largest markets worldwide. Orchids are consistently ranked among the best sellers in the global potted plant trade and comprise $10 \%$ of all fresh cut flowers traded internationally. Exports of potted orchids from the Netherlands alone were valued at ca. 500 M euro in 2015 (Hinsley et al. 2018). Production is expanding rapidly in Asia, mainly in Thailand and China but also in Eastern Europe, with exports directed to the European market, United States and Japan (Hinsley et al. 2018). This industry is particularly sensitive to bacterial diseases as production costs are relatively high and growth conditions are extremely conducive to bacterial spread. Several reports on soft rot infections in orchids are found in the literature (Cating et al. 2008; Cating and Palmateer 2011; Cating et al. 2009). Most losses in orchids are caused by Dickeya spp., although infections with Pectobacterium spp. have also been reported (Charkowski 2018; Dahaghin and Shams-Bakhsh 2014; Alic et al. 2015; Cating and Palmateer 2011; Table 3.1).

The globalization of the flower industry, with its expansion to Latin America, Africa and Asia, and with increasing exports to Europe, United States, Canada and Japan have assisted dissemination of soft rot pathogens, e.g. D. solani and $P$. brasiliense on potato in Europe (see Chap. 8), supported by the latent nature of the pathogen in plant propagation material (Charkowski 2018). The large number of crops and worldwide transportation and trade make this industry extremely vulnerable to the spread of bacterial pathogens. Climate change and global warming support this trend and allow strains from warm climate countries to invade and proliferate in more temperate zones. Such outbreaks are largely dependent on the transfer and quality of the propagation material, the environmental conditions (temperature and humidity), growing conditions (soil, substrates, nutrition), irrigation systems and the presence of vectors such as insects and human. Semi-controlled environments such as greenhouses and covered tunnels, which are common to cultivation of ornamental 
plants, allow growers to have better control of the climate conditions (temperature, hail and precipitation) but also provide favourable conditions for infection. Accordingly, control measures include strict sanitation procedures, starting with clean and healthy plant material, achieved by sorting out poor quality or disease suspected material (Chastagner et al. 2013; Czajkowski et al. 2011b).

Such management proved to be highly efficient in the case of carnation (Dianthus) bacterial stunt disease caused by $D$. dianthicola. $D$. dianthicola was first detected in carnation in 1956 and more than $25 \%$ of mother stock plants were reported to be affected (Hellmers 1958). Severe outbreaks continued in the 1960s and 1970s leading to the classification of $D$. dianthicola as a quarantine pest in carnation. Certification schemes and very strict hygienic and sanitation measures where implemented, including the use of pathogen-free in vitro plants as starting material for cuttings propagation, steam sterilisation to disinfect growth substrates and surfaces, disinfection of tools and use of sterilized or filtered water for irrigation, growth on elevated benches to reduce the risk of water logging, and use of insect-proof contained areas in glasshouses. Furthermore, in field production, machines and materials used in carnation production rarely now come into contact with other crops considered as important hosts of $D$. dianthicola, e.g. potato and dahlia. The implementation of a certification scheme together with these strict sanitation procedures used in the production of planting material, have been very effective in controlling $D$. dianthicola, resulting in little damage being recorded in recent years (EFSA 2013a, b) and leading to the dropping of the quarantine status for D. dianthicola. This method is now also the mainstay of SRP control in other horticultural (ornamental) crops (Altman and Loberant 1997).

Unfortunately, diagnosis and detection of SRP are not yet applied on a wide scale in the flower bulb industry, mostly due to cost considerations. When cost effective, growers prefer in vitro tissue culture produced plantlets in order to start with pathogen-free propagation material. Keeping the sanitation of the packing house during processing of bulbs, control of storage conditions (including temperature, humidity and aeration) at all phases, and temperature-controlled transportation, may all help to prevent contamination and disease outbreak. Soil or growing media sanitation is also an important factor, especially in greenhouses where soil-free mixtures can be easily treated by steam-pasteurization, chemicals or soil solarization (Chastagner et al. 2013). Growth conditions could be further optimized to limit soft rot disease, mainly through reducing humidity by limiting irrigation, increasing aeration, improving soil drainage and by optimizing plant nutrition with an emphasis on calcium fertilization. Only mature bulbs should be harvested and wounds and contaminations should be avoided during harvest and transport. Inspections for and control of soft rot diseases should also be carried out to avoid transmission of the bacteria and secondary infection of injured plants.

The potential of biocontrol agents (BCA) was explored to control soft rot in ornamental calla lily plants caused by $P$. carotovorum ( $\mathrm{Li}$ et al. 2018). In this study, bacteria from Myxococcus spp. were selected as a potential BCA. Myxococcus spp. are saprophytic bacteria that grow on dead organic matter and exhibit multicellular swarming behavior called "wolf-pack", which facilitates predatory feeding on other 
microorganisms. This feature prompted researchers to screen isolates of myxobacteria from soil collected in different regions of China. From 12 isolates obtained, the one that showed the greatest swarming capacity, classified as Myxococcus sp. strain BS, was selected for pot experiments. Myxососсиs spp. can produce antimicrobials, although the most important mechanism of antagonism in strain BS against $P$. carotovorum was found to be a direct cell-to-cell contact and predatory behaviour of the BS strain. The BS strain significantly reduced the soft rot incidence when applied together with $P$. carotovorum to soil and showed growth promotion in potato plants as it was able to increase the number of progeny tubers.

In ornamentals, resistance against SRP was found after introducing genes that expressed antimicrobial peptides into plants. Phalaenopsis plants displayed resistance against $P$. carotovorum after introduction of the wasabi defensin gene (Sjahril et al. 2006). Ornithogalum, which express the antimicrobial peptide tachyplesin I of the Asian horseshoe crab in transgenic lines showed resistance to Pectobacterium infections (Lipsky et al. 2016).

Overall, however, in a similar way to other agricultural systems, scientific advances that have been made in the laboratory and experimental systems have not yet been translated into available products in ornamental horticulture to prevent disease (Chastagner et al. 2013). Nonetheless, implementation and dissemination of integrated pest management practices and the importance of cultural management help the bulb growers to improve and manage soft rot bacteria.

\subsubsection{Concluding Remarks}

Due to the broad host range of several SRP spp., infections in chicory and ornamentals may have implications for potato production and vice versa. Indeed, isolates of Dickeya spp. from potato plants with blackleg disease can macerate chicory heads and, even if symptoms in chicory are rare in the field, chicory might be a reservoir for SRP that subsequently affect potato. This is particularly important because, in certain regions, chicory is part of the same crop rotation programs used for potato cultivation. Some farms produce both potato and flowers and it was hypothesized that outbreaks of blackleg on potato in the 2000 s was caused by a strain of $D$. solani that originated from greenhouse-grown ornamentals (Sławiak et al. 2009).

\subsection{Final Conclusions}

After years of research, the set of tools available for the management of SRP and the diseases they cause is still limited, mostly comprising tools that have been available for many years. During potato cropping hygiene, the use of (certified) pathogen free starting material, crop rotation, the use of cultivars less susceptible for SRP, the avoidance of water logging and the avoidance of crop damage are among these tools. 
Harvesting under dry weather conditions plays a key role in management of both blackleg and soft rot diseases, preferably when mother tubers are no longer present. If possible, rotten tubers should be removed from machines and tuber wounding avoided. Drying of harvested tubers and storage in well-ventilated rooms at low temperatures are essential to avoid multiplication of SRP and tuber decay. Crop growth under contained conditions will also help to avoid the introduction of SRP, including new variants present in wider agricultural ecosystems. For management of soft rot diseases in crops that are grown in contained facilities, the control of environmental conditions (particularly temperature and humidity) and optimization of nutrition are key elements in the management of SRP.

Major breakthroughs in the fight against SRP related diseases are not expected in the short term. Nevertheless, there are new management tools, strategies and germplasm being developed and tested. New breeding techniques may allow the introduction of resistance genes in commercial cultivars, while, although the use of true potato seed is still in its infancy, it is expected to become a powerful tool in eliminating disease problems in the future. Biocontrol agents are also in development although, while laboratory studies have been successful, in-field applications need to be improved. We may also see the increased use of beneficial microbes in the form of bio-inoculants. The availability of reliable and sensitive methods that can act on all relevant SRP variants remains an important consideration in the development and evaluation of new management tools.

\section{References}

Adriaenssens EM, Van Vaerenbergh J, Vandenheuvel D, Dunon V, Ceyssens P-J, De Proft M, Kropinski AM, Noben J-P, Maes M, Lavigne R (2012) T4-Related bacteriophage LIMEstone isolates for the control of soft rot on potato caused by 'Dickeya solani'. PLoS ONE 7(3):e33227

Afek U, Orenstein J (2002) Disinfecting potato tubers using steam treatments. Can J Plant Path 24(1):36-39

Alic S, Naglic T, Llop P, Toplak N, Koren S, Ravnikar M, Dreo T (2015) Draft genome ssquences of Dickeya sp. Isolates B16 (NIB Z 2098) and S1 (NIB Z 2099) causing soft rot of Phalaenopsis orchids. Genome Announc 3(5)

Allefs JJHM, Van Dooijeweert W, De Jong ER, Prummel W, Hoogendoorn J (1995) Factors affecting potato soft-rot resistance to pectolytic Erwinia species in a tuber-slice assay. J Phytopathol 143(11-12):705-711

Allefs JJHM, Van Dooijeweert W, Prummel W, Keizer LCP, Hoogendoorn J (1996) Components of partial resistance to potato blackleg caused by pectolytic Erwinia carotovora subsp. atroseptica and E. chrysanthemi. Plant Pathol 45(3):486-496

Altman A, Loberant B (1997) Micropropagation: clonal plant propagation in vitro. Agricultural biotechnology. CRC Press, Jerusalem, Israel, pp 19-42

Ansermet M, Schaerer S, Kellenberger I, Tallant M, Dupuis B (2016) Influence of seed-borne and soil-carried inocula of Dickeya spp. on potato plant transpiration and symptom expression. Eur J Plant Pathol 145(2):459-467

Arce P, Moreno M, Gutierrez M, Gebauer M, Dell'Orto P, Torres H, Acuña I, Oliger P, Venegas A, Jordana X (1999) Enhanced resistance to bacterial infection by Erwinia carotovora subsp. 
atroseptica in transgenic potato plants expressing the attacin or the cecropin SB-37 genes. Am J Potato Res 76(3):169-177

Avinash VS, Panigrahi P, Suresh CG, Pundle AV, Ramasamy S (2013) Structural modelling of substrate binding and inhibition in penicillin V acylase from Pectobacterium atrosepticum. Biochem Biophys Res Commun 437(4):538-543

Baghaee Ravari S, Moslemkhani K, Khodaygan P (2013) Assessment of genetic variability of prevalent pectinolytic bacteria causing potato tuber soft rot in eastern Iran. J Plant Pathol 95(1):107-113

Bains Piara S, Bisht Vikram S, Lynch Dermot R, Kawchuk Lawrence M, Helgeson John P (1999) Identification of stem soft rot (Erwinia carotovora subspecies atroseptica) resistance in potato. Am J Potato Res 76(3):137-141

Bain RA, Millard P, Perombelon MCM (1996) The resistance of potato plants to Erwinia carotovora subsp. atroseptica in relation to their calcium and magnesium content. Potato Res 39(1):185-193

Bakker PA, Glandorf DC, Viebahn M, Ouwens TW, Smit E, Leeflang P, Wernars K, Thomashow LS, Thomas-Oates JE, van Loon LC (2002) Effects of Pseudomonas putida modified to produce phenazine-1-carboxylic acid and 2, 4-diacetylphloroglucinol on the microflora of field grown wheat. Antonie Van Leeuwenhoek 81(1-4):617-624

Bakker PA, Pieterse CM, Van Loon L (2007) Induced systemic resistance by fluorescent Pseudomonas spp. Phytopathology 97(2):239-243

Balogh B, Jones JB, Iriarte F, Momol M (2010) Phage therapy for plant disease control. Curr Pharm Biotechnol 11(1):48-57

Bangemann L-W, Sieling K, Kage H (2014) The effect of nitrogen and late blight on crop growth, solar radiation interception and yield of two potato cultivars. Field Crops Res 155:56-66

Barbey C, Crépin A, Bergeau D, Ouchiha A, Mijouin L, Taupin L, Orange N, Feuilloley M, Dufour A, Burini JF, Latour X (2013) In planta biocontrol of Pectobacterium atrosepticum by Rhodococcus erythropolis involves silencing of pathogen communication by the rhodococcal gamma-lactone catabolic pathway. PLoS ONE 8(6)

Barone A, Sebastiano A, Carputo D, della Rocca F, Frusciante L (2001) Molecular marker-assisted introgression of the wild Solanum commersonii genome into the cultivated $S$. tuberosum gene pool. Theor Appl Genet 102(6-7):900-907

Barras F, van Gijsegem F, Chatterjee AK (1994) Extracellular enzymes and pathogenesis of soft-rot Erwinia. Annu Rev Phytopathol 32(1):201-234

Barrell PJ, Conner AJ (2009) Expression of a chimeric magainin gene in potato confers improved resistance to the phytopathogen Erwinia carotovora. Open Plant Sci J 3:14-21

Bartz JA, Kelman A (1986) Reducing the potential for bacterial soft rot in potato tubers by chemical treatments and drying. Am Potato J 63(9):481-493

Baştaş KK, Hekimhan H, Maden S, Tör M (2009) First report of bacterial stalk and head rot disease caused by Pectobacterium atrosepticum on sunflower in Turkey. Plant Dis 93(12):1352-1352

Beneduzi A, Ambrosini A, Passaglia LM (2012) Plant growth-promoting rhizobacteria (PGPR): their potential as antagonists and biocontrol agents. Genet Mol Biol 35(4):1044-1051

Benschop M, Kamenetsky R, Le Nard M, Okubo H, De Hertogh A (2010) The global flower bulb industry: production, utilization, research. In: Janick J (ed) Horticultural reviews, vol 36. Wiley-Blackwell

Bonde R (1950) Factors affecting potato blackleg and seed-piece decay. The Maine agricultural experiment station, Orno, Maine

Bontemps-Gallo S, Madec E, Dondeyne J, Delrue B, Robbe-Masselot C, Vidal O, Prouvost AF, Boussemart G, Bohin JP, Lacroix JM (2013) Concentration of osmoregulated periplasmic glucans (OPGs) modulates the activation level of the RcsCD RcsB phosphorelay in the phytopathogen bacteria Dickeya dadantii. Environ Microbiol 15(3):881-894

Boomsma D, Kastelein P, Van der Zouwen PS, Krijger M, Förch M, Van der Wolf J, Czajkowski C, Wegierek A, Jafra S, Van den Bovenkamp G, De haan E, Nunes Leite L (2012) Het project "Deltaplan Erwinia Deel C - Pootaardappelen. Eindrapport van het onderzoek 209-2012. Nederlandse Aardappel Organisatie, Den Haag 
Bouvard E (1987) Implication d'Erwinia sp dans une pourriture molle de Cichorium intybus L. au forçage. Thèse Université Paris Sud

Boydston RA, Seymour MD, Brown CR, Alva AK (2006) Freezing behavior of potato (Solanum tuberosum) tubers in soil. Am J Potato Res 83(4):305-315

Burgess PJ, Blakeman JP, Perombelon MCM (1994) Contamination and subsequent multiplication of soft rot erwinias on healthy potato leaves and debris after haulm destruction. Plant Pathol 43(2):286-299

Burra DD, Mühlenbock P, Andreasson E (2015) Salicylic and jasmonic acid pathways are necessary for defence against Dickeya solani as revealed by a novel method for blackleg disease screening of in vitro grown potato. Plant Biol 17(5):1030-1038

Byther RS, Chastagner GA (1993) Diseases. In: De Hertogh A, Le Nard M (eds) The physiology of flower bulbs. Elsevier Science, Amsterdam, Netherlands, pp 71-100

Carputo D, Terra A, Barone A, Esposito F, Fogliano V, Monti L, Frusciante L (2003) Glycoalkaloids and acclimation capacity of hybrids between Solanum tuberosum and the incongruent hardy species Solanum commersonii. Theor Appl Genet 107(7):1187-1194

Cating RA, Palmateer AJ (2011) Bacterial soft rot of oncidium orchids caused by a Dickeya sp. (Pectobacterium chrysanthemi) in Florida. Plant Dis 95(1):74. https://doi.org/10.1094/PDIS-0710-0523

Cating RA, Hong JC, Palmateer AJ, Stiles CM, Dickstein ER (2008) First report of bacterial soft rot on vanda orchids caused by Dickeya chrysanthemi (Erwinia chrysanthemi) in the United States. Plant Dis 92(6):977

Cating RA, Palmateer AJ, McMillan RT, Dickstein ER (2009) First report of a bacterial soft rot on Tolumnia orchids caused by a Dickeya sp. in the United States. Plant Dis 93(12):1354

Charkowski AO (2015) Biology and control of Pectobacterium in potato. Am J Potato Res 92(2):223-229

Charkowski AO (2018) The changing face of bacterial soft-rot diseases. Annu Rev Phytopathol $56: 269-288$

Chastagner GA, Hanks GR, Daughtrey ML, Yedidia I, Miller TW, Pappu HR (2013) Sustainable production and integrated management: environmental Issues In: Kamenetsky R, Okubo H (eds) Ornamental geophytes: from basic science to sustainable production. CRC Press, Taylor \& Francis Group, Boca Raton, FL, USA, pp 363-405

Chung YS, Goeser NJ, Cai X, Jansky S (2013) The effect of long term storage on bacterial soft rot resistance in potato. Am J Potato Res 90(4):351-356

Compant S, Clément C, Sessitsch A (2010) Plant growth-promoting bacteria in the rhizo-and endosphere of plants: their role, colonization, mechanisms involved and prospects for utilization. Soil Biol Biochem 42(5):669-678

Cooke LR, Schepers HTAM, Hermansen A, Bain RA, Bradshaw NJ, Ritchie F, Shaw DS, Evenhuis A, Kessel GJT, Wander JGN, Andersson B, Hansen JG, Hannukkala A, Naerstad R, Nielsen BJ (2011) Epidemiology and integrated control of potato late blight in Europe. Potato Res 54(2):183222

Coons G, Kotila J (1925) The transmissible lytic principle (bacteriophage) in relation to plant pathogens. Phytopathology 15:357-370

Czajkowski R, Jafra S (2009) Quenching of acyl homoserine lactones-dependent quorum sensing by enzymatic disruption of signal molecules. Acta Biochim Pol 56:1-16

Czajkowski R, Boer WJ, Velvis H, Wolf JM (2010) Systemic colonization of potato plants by a soilborne, green fluorescent protein-tagged strain of Dickeya sp. biovar 3. Phytopathology 100

Czajkowski R, Krzyżanowska D, Karczewska J, Atkinson S, Przysowa J, Lojkowska E, Williams P, Jafra S (2011a) Inactivation of AHLs by Ochrobactrum sp. A44 depends on the activity of a novel class of AHL acylase. Environ Microbiol Rep 3(1):59-68

Czajkowski R, Perombelon MCM, van Veen JA, van der Wolf JM (2011b) Control of blackleg and tuber soft rot of potato caused by Pectobacterium and Dickeya species: a review. Plant Pathol 60(6):999-1013 
Czajkowski R, de Boer WJ, van der Zouwen PS, Kastelein P, Jafra S, de Haan EG, van den Bovenkamp GW, van der Wolf JM (2012a) Virulence of 'Dickeya solani' and Dickeya dianthicola biovar-1 and -7 strains on potato (Solanum tuberosum). Plant Pathol 62:597-610

Czajkowski R, de Boer WJ, van Veen JA, van der Wolf JM (2012b) Studies on the interaction between the biocontrol agent, Serratia plymuthica A30, and blackleg-causing Dickeya sp (biovar 3) in potato (Solanum tuberosum). Plant Pathol 61(4):677-688

Czajkowski R, De Boer W, Van der Wolf J (2013) Chemical disinfectants can reduce potato blackleg caused by 'Dickeya solani'. Eur J Plant Pathol 136(2):419-432

Czajkowski R, Ozymko Z, Lojkowska E (2014) Isolation and characterization of novel soilborne lytic bacteriophages infecting Dickeya spp. biovar 3 ('D. solani'). Plant Pathol 63(4):758-772

Czajkowski R, van der Wolf J, Krolicka A, Ozymko Z, Narajczyk M, Kaczynska N, Lojkowska E (2015) Salicylic acid can reduce infection symptoms caused by Dickeya solani in tissue culture grown potato (Solanum tuberosum L.) plants. Eur J Plant Pathol 141(3):545-558

Dahaghin L, Shams-Bakhsh M (2014) Identification and genetic diversity of pectolytic phytopathogenic bacteria of mono- and dicotyledonous ornamental plants in Iran. J Plant Pathol 96(2):271-279

da Silva Felix KC, da Silva CL, de Oliveira WJ, de Lima Ramos Mariano R, de Souza EB (2017) Calcium-mediated reduction of soft rot disease in Chinese cabbage. Eur J Plant Pathol 147(1):7384

Davis JR, Garner JG, Callihan RH (1974) Effects of gypsum, sulfur, terraclor and terraclor super-x for potato scab control. Am Potato J 51(2):35-43

De Boer SH, Kelman A (1978) Influence of oxygen concentration and storage factors on susceptibility of potato tubers to bacterial soft rot (Erwinia carotovora). Potato Res 21(1):65-79

De Boer SH, Li X, Ward LJ (2012) Pectobacterium spp. associated with bacterial stem rot syndrome of potato in Canada (Phytopathology). Phytopathology 102(10):937-947

De Haan J, Garcia Diaz A (2002) Manual on prototyping methodology and multifunctional crop rotation. Vegineco, Project Report No. 2. Lelystad, The Netherlands

De Hertogh A, van Scheepen J, Le Nard M, Okubo H, Kamenetsky R (2013) Globalization of the flower bulb industry. In: Kamenetsky R, Okubo H (eds) Ornamental geophytes: from basic science to sustainable production, vol 1. CRC Press, Boca Raton, FL, USA, p 578

Des Essarts YR, Cigna J, Quêtu-Laurent A, Caron A, Munier E, Beury-Cirou A, Hélias V, Faure D (2016) Biocontrol of the potato blackleg and soft rot diseases caused by Dickeya dianthicola. Appl Environ Microbiol 82(1):268-278

Dodd A, Kudla J, Sanders D (2010) The language of calcium signaling, vol 61

Dong Yi H, Xu Jin L, Li Xian Z, Zhang Lian H (2000) AiiA, an enzyme that inactivates the acylhomoserine lactone quorum-sensing signal and attenuates the virulence of Erwinia carotovora. In: Proceedings of the national academy of sciences of the United States of America, vol 97, no 7, pp 3526-3531, 28 March 2000

Dong Yi H, Wang Lian H, Xu Jin L, Zhang Hai B, Zhang Xi F, Zhang Lian H (2001) Quenching quorum-sensing-dependent bacterial infection by an $\mathrm{N}$-acyl homoserine lactonase. Nature 411(6839):813-817

Dong YH, Zhang XF, Xu JL, Zhang LH (2004) Insecticidal Bacillus thuringiensis silences Erwinia carotovora virulence by a new form of microbial antagonism, signal interference. Appl Environ Microbiol 70(2):954-960

Dubois Gill E, Schaerer S, Dupuis B (2014) Factors impacting blackleg development caused by Dickeya spp. in the field. Eur J Plant Pathol 140(2):317-327

Dzimitrowicz A, Motyka A, Jamroz P, Lojkowska E, Babinska W, Terefinko D, Pohl P, Sledz W (2018) Application of silver nanostructures synthesized by cold atmospheric pressure plasma for inactivation of bacterial phytopathogens from the genera Dickeya and Pectobacterium. Materials 11(3):331

Eayre CG, Bartz JA, Concelmo DE (1995) Bacteriophages of Erwinia carotovora and Erwinia ananas isolated from freshwater lakes. Plant Dis 79(8):801-804

EFSA (2013a) Dickeya dianthicola pest risk assessment EFSA J 11(1):3072 
EFSA (2013b) Scientific Opinion on the risk of Dickeya dianthicola for the EU territory with identification and evaluation of risk reduction options. EFSA J 11(1):115

Elmer WH, Datnoff LE (2014) Mineral nutrition and suppression of plant disease. In: Van Alfen NK (ed) Encyclopedia of agriculture and food systems. Academic Press, Oxford, pp 231-244

Elphinstone JG, Perombelon MCM (1986) Contamination of potatoes by Erwinia carotovora during grading. Plant Pathol Oxford 35(1):25-33

Elphinstone JG, Toth I (2007) Erwinia chrysanthemi (Dickeya spp.) (2007) The facts British potato council publication, p 25. https://www.veksthusinfo.no/dokument/1372763830.pdf

Elphinstone JG, Cahill G, Davey T, Harper G, Humphris S, Saddler GS, Toth IK, Wale S (2018) Effect of storage conditions on bacterial loading of seed potato tubers. Review, AHDB potato, Kenilworth, UK

Expert D, Enard C, Masclaux C (1996) The role of iron in plant host-pathogen interactions. Trends Microbiol 4(6):232-237

Farrar JJ, Nunez JJ, Davis RM (2000) Influence of soil saturation and temperature on Erwinia chrysanthemi soft rot of carrot. Plant Dis 84(6):665-668

Franc GD, Harrison MD, Powelson ML (1984) The presence of Erwinia carotovora in ocean water, rain water and aerosols. In: Paper presented at the international conference on potato blackleg disease, Edinburgh, 26-29 June 1984

Fritz V, Honma S (1987) The effect of raised beds, population densities, and planting date on the incidence of bacterial soft rot in Chinese cabbage

Fukuoka S, Howe J, Andrä J, Gutsmann T, Rössle M, Brandenburg K (2008) Physico-chemical and biophysical study of the interaction of hexa- and heptaacyl lipid A from Erwinia carotovora with magainin 2-derived antimicrobial peptides. Biochimica et Biophysica Acta (BBA)—Biomembranes 1778(10):2051-2057

Funnell K, Mackay BR (1999) Directions and challenges of the New Zealand calla industry, and the use of calcium to control soft rot. In: Paper presented at the international symposium on development of bulbous flower industry, Taichung, Taiwan, January 1999

Garge SS, Nerurkar AS (2017) Evaluation of quorum quenching Bacillus spp. for their biocontrol traits against Pectobacterium carotovorum subsp. carotovorum causing soft rot. Biocatal Agric Biotechnol 9:48-57

Gerayeli N, Baghaee-Ravari S, Tarighi S (2018) Evaluation of the antagonistic potential of Bacillus strains against Pectobacterium carotovorum subsp. carotovorum and their role in the induction of resistance to potato soft rot infection. Eur J Plant Pathol 150(4):1049-1063

Gill ED, Schaerer S, Dupuis B (2014) Factors impacting blackleg development caused by Dickeya spp. in the field. Eur J Plant Pathol 140(2):317-327

González-Rodríguez MÁ, Silva-Rojas HV, Mascorro-Gallardo JO (2005) Ensayo in vitro del péptido antimicrobiano melitina contra diferentes bacterias fitopatógenas. Revista Mexicana De Fitopatología 23(2):176-182

Goto K (1985) Relationships between soil $\mathrm{pH}$, available calcium and prevalence of potato scab. Soil Sci Plant Nutr 31(3):411-418

Graham DC, Harper PC (1966) Effect of inorganic fertilizers on the incidence of potato blackleg disease. Eur Potato J 9(3):141-145

Graham DC, Quinn CE, Bradley LF (1977) Quantitative studies on the generation of aerosols of Erwinia carotovora var. atroseptica by simulated raindrop impaction on blackleg infected potato stems. J Appl Bacteriol 43(3):413-424

Grandclément C, Tannières M, Moréra S, Dessaux Y, Faure D (2016) Quorum quenching: role in nature and applied developments. FEMS Microbiol Rev 40(1):86-116

Hadizadeh I, Peivastegan B, Hannukkala A, van der Wolf J, Nissinen R, Pirhonen M (2019) Biological control of potato soft rot caused by Dickeya solani and the survival of bacterial antagonists under cold storage conditions. Plant Pathol 68(2):297-311

Hameed A, Zaidi SS-EA, Shakir S, Mansoor S (2018) Applications of new breeding technologies for potato improvement. Front Plant Sci 9:925-925 
Harris R (1979) Chemical control of bacterial soft-rot of wounded potato tubers. Potato Res 22(3):245-249

Haverkort A, Struik P (2015) Yield levels of potato crops: recent achievements and future prospects. Field Crops Res 182:76-85

Hellmers E (1958) Four wilt diseases of perpetual flowering carnations in Denmark. Dansk Botanisk Arkiv 18:95-140

Hinsley A, De Boer HJ, Fay FM, Gale SW, Gardiner LM, Gunasekara RS, Kumar P, Masrers S, Metusala D, Roberts DL, Veldman S, Wong S, Phelps J (2018) A review of the trade in orchids and its implications for conservation. Bot J Linnean Soc 186:435-455

Huber DM, Thompson IA (2007) Nitrogen and plant disease. In: Datnoff LE, Elmer WH, Huber DM (eds) Mineral nutrition and plant disease. American Phytopathological Society, St. Paul, MN, pp 31-44

Huber D, Römheld V, Weinmann M (2012) Chapter 10-Relationship between nutrition, plant diseases and pests. In: Marschner P (ed) Marschner's mineral nutrition of higher plants, 3rd edn. Academic Press, San Diego, pp 283-298

Jafra S, Przysowa J, Gwizdek-Wisniewska A, van der Wolf JM (2009) Potential of bulb-associated bacteria for biocontrol of hyacinth soft rot caused by Dickeya zeae. J Appl Microbiol 106(1):268277

Jansky S (2000) Breeding for disease resistance in potato, vol 19. Plant Breeding Reviews. Wiley, Hoboken, USA

Jia H, Zhang Y, Orbović V, Xu J, White FF, Jones JB, Wang N (2017) Genome editing of the disease susceptibility gene Cs LOB 1 in citrus confers resistance to citrus canker. Plant Biotechnol J 15(7):817-823

Johnson DA, Dung JK, Cummings TF, Schroeder BK (2011) Development and suppression of aerial stem rot in commercial potato fields. Plant Dis 95(3):285-291

Jung Y-J, Choi C-S, Park J-H, Kang H-W, Choi J-E, Nou I-S, Lee SY, Kang K-K (2008) Overexpression of the pineapple fruit bromelain gene (BAA) in transgenic Chinese cabbage (Brassica rapa) results in enhanced resistance to bacterial soft rot. Electron J Biotechnol 11(1):71-79

Kastelein P, Evenhuis A, Van der Zouwen P, Krijger M, Van der Wolf J (2018) Spread of Xanthomonas fragariae in strawberry fields by machinery. EPPO Bull 48(3):569-577

Kastelein P, Förch MG, Krijger MC, Van der Zouwen PS, Van den Berg W, Van der Wolf JM (2020) Systemic colonization of potato plants resulting from potato haulm inoculation with Dickeya solani or Pectobacterium parmentieri. Can J Plant Pathol (in press)

Kempenaar C, Struik PC (2007) The canon of potato science: 33 Haulm Killing. Potato Res 50(34):341-345

Kerlan C, Robert Y, Perennec P, Guiller E (1987) Mise au point sur l'incidence du virus Y o et méthodes de lutte mises en oeuvre en France pour la production de semences de pommes de terre. Potato Res 30(4):651-667

Kloepper JW (1983) Effect of seed piece inoculation with plant growth promoting rhizobacteria on populations of Erwinia carotovora on potato roots and in daughter tubers. Phytopathology 73(2):217-219

Knowles NR, Iritani WM, Weiler LD, Gross DC (1982) Susceptibility of potatoes to bacterial rot and weight loss as a function of wound-healing interval and temperature. Am Potato J 59(11):515-522

Krzyzanowska D, Obuchowski M, Bikowski M, Rychlowski M, Jafra S (2012a) Colonization of potato rhizosphere by GFP-tagged Bacillus subtilis MB73/2, Pseudomonas sp. P482 and Ochrobactrum sp. A44 shown on large sections of roots using enrichment sample preparation and confocal laser scanning microscopy. Sensors 12(12):17608-17619

Krzyzanowska DM, Potrykus M, Golanowska M, Polonis K, Gwizdek-Wisniewska A, Lojkowska E, Jafra S (2012b) Rhizosphere bacteria as potential biocontrol agents against soft rot caused by various Pectobacterium and Dickeya spp. strains. J Plant Pathol 94(2):367-378

Krzyżanowska DM, Ossowicki A, Rajewska M, Maciąg T, Jabłońska M, Obuchowski M, Heeb S, Jafra S (2016) When genome-based approach meets the "old but good": revealing genes involved 
in the antibacterial activity of Pseudomonas sp. P482 against soft rot pathogens. Front Microbiol 7:782

Kushalappa AC, Zulfiquar M (2001) Effect of wet incubation time and temperature on infection, and of storage time and temperature on soft rot lesion expansion in potatoes inoculated with Erwinia carotovora ssp. carotovora. Potato Res 4(3):233-242

Lambert HD (1991) Relationship of calcium to potato scab, vol 81

Lambert DH, Powelson ML, Stevenson WR (2005) Nutritional interactions influencing diseases of potato. Am J Potato Res 82(4):309-319

Laurila J, Ahola V, Lehtinen A, Joutsjoki T, Hannukkala A, Rahkonen A (2008) Characterization of Dickeya strains isolated from potato and river water samples in Finland. Eur J Plant Pathol 122:213-225

Laville J, Benigni M (1997) La tolérance variétale aux maladies, élément de lutte raisonnée contre les parasites de l'endive. XIVème Biennale internationale de l'endive, Arras, France, 28-31. FNPE Edition

Lebecka R (2017) Screening for potato resistance to blackleg and soft rot. Plant Breed Seed Sci 75(1):97-104

Lebecka R, Zimnoch-Guzowska E, Kaczmarek Z (2005) Resistance to soft rot (Erwinia carotovora subsp. atroseptica) in tetraploid potato families obtained from 4x-2x crosses. Am J Potato Res 82(3):203-210

Lecourieux D, Ranjeva R, Pugin A (2006) Calcium in plant defence-signalling pathways. New Phytol 171(2):249-269

Le Guern J, Tirilly Y, Le Picard D, Le Ster D (1992) Bacterial rot of witloof chicory roots caused by Erwinia chrysanthemi. Plant Pathol 41:228-231

Le Hingrat Y, Hélias V, Le Roux-Nio A, Cellier G, Prior P, Rivoal C, Poliakof F, Soubelet H, Moreau M, Deveaux V, Latour X, Guaucher D, Benigni M, Martinon V (2012) Evaluation (et gestion) des risques sanitaires bactérien liés aux itenéraires culturaux de la pomme de terre et d'autres cultures spécialisées. Innov Agronomiques 25:253-267

Lindhout P, Meijer D, Schotte T, Hutten RCB, Visser RGF, van Eck HJ (2011) Towards F1 hybrid seed potato breeding. Potato Res 54(4):301-312

Lipsky A, Joshi JR, Carmi N, Yedidia I (2016) Expression levels of antimicrobial peptide tachyplesin I in transgenic Ornithogalum lines affect the resistance to Pectobacterium infection. J Biotechnol 238:22-29

Li Z, Wang T, Luo X, Li X, Xia C, Zhao Y, Ye X, Huang Y, Gu X, Cao H, Cui Z, Fan J (2018) Biocontrol potential of Myхососси sp. strain BS against bacterial soft rot of calla lily caused by Pectobacterium carotovorum. Biol Control 126:36-44

Lorenc-Kukuła K, Jafra S, Oszmiański J, Szopa J (2005) Ectopic expression of anthocyanin 5-Oglucosyltransferase in potato tuber causes increased resistance to bacteria. J Agric Food Chem 53(2):272-281

Lumb VM, Perombelon MCM, Zutra D (1986) Studies of a wilt disease of the potato plant in israel caused by Erwinia chrysanthemi. Plant Pathol 35(2):196-202

Lutman PJ (1977) Investigations into some aspects of the biology of potatoes as weeds. Weed Res 17:123-132

Luzzatto T, Yishay M, Lipsky A, Ion A, Belausov E, Yedidia I (2007) Efficient, long-lasting resistance against the soft rot bacterium Pectobacterium carotovorum in calla lily provided by the plant activator methyl jasmonate. Plant Pathol 56(4):692-701

Ma B, Hibbing ME, Kim HS, Reedy RM, Yedidia I, Breuer J, Breuer J, Glasner JD, Perna NT, Kelman A, Charkowski AO (2007) Host range and molecular phylogenies of the soft rot enterobacterial genera Pectobacterium and Dickeya. Phytopathology 97(9):1150-1163

Mahmoudi E, Naderi D, Venturi V (2013) AiiA lactonase disrupts N-acylhomoserine lactone and attenuates quorum-sensing-related virulence in Pectobacterium carotovorum EMPCC. Ann Microbiol 63(2):691-697

Mallmann W, Hemstreet C (1924) Isolation of an inhibitory substance from plants. Agric Res 28:599-602 
Maltas A, Dupuis B, Sinaj S (2018) Yield and quality response of two potato cultivars to nitrogen fertilization. Potato Res 61(2):97-114

Mantsebo CC, Mazarura U, Goss M, Ngadze E (2014) The epidemiology of Pectobacterium and Dickeya species and the role of calcium in postharvest soft rot infection of potato (Solanum tuberosum) caused by the pathogens: a review. Afr J Agric Res 9(19):1509-1515

Marquez-Villavicencio MdP, Groves RL, Charkowski AO (2011) Soft rot disease severity is affected by potato physiology and Pectobacterium taxa. Plant Dis 95(3):232-241

Matilla MA, Krell T (2018) Plant growth promotion and biocontrol mediated by plant-associated bacteria. In: Plant microbiome: stress response. Springer, pp 45-80

McDougald D, Rice SA, Weichart D, Kjelleberg S (1998) Nonculturability: adaptation or debilitation? FEMS Microbiol Ecol 25(1):1-9

McGovern RJ, Horst RK, Dickey RS (1985) Effect of plant nutrition on susceptibility of Chrysanthemum morifolium to Erwinia chrysanthemi. Plant Dis 69:1086-1088

McGuire RG, Kelman A (1984) Reduced severity of Erwinia soft rot in potato tubers with increased calcium content. Phytopathology 74:1250-1256

McGuire RG, Kelman A (1986) Calcium in potato tuber cell walls in relation to tissue maceration by Erwinia carotovora pathovar atroseptica. Phytopathology 76(4):401-406

McMillan GP, Hedley D, Fyffe L, Perombelon MCM (1993) Potato resistance to soft-rot erwinias is related to cell wall pectin esterification. Physiol Mol Plant Pathol 42(4):279-289

Mhedbi-Hajri N, Malfatti P, Pédron J, Gaubert S, Reverchon S, Van Gijsegem F (2011) PecS is an important player in the regulatory network governing the coordinated expression of virulence genes during the interaction between Dickeya dadantii 3937 and plants. Environ Microbiol 13:2901-2914

Mills A, Hurta R (2006) Sensitivity of Erwinia spp. to salt compounds in vitro and their effect on the development of soft rot in potato tubers in storage. Postharvest Biol Technol 41(2):208-214

Mohan S, Meiyalaghan S, Latimer JM, Gatehouse ML, Monaghan KS, Vanga BR, Pitman AR, Jones EE, Conner AJ, Jacobs JME (2013) GSL2 over-expression confers resistance to Pectobacterium atrosepticum in potato. Theor Appl Genet 1-13

Moh AA, Massart S, Lahlali R, Jijakli M, Lepoivre P (2011) Predictive modelling of the combined effect of temperature and water activity on the in vitro growth of Erwinia spp. infecting potato tubers in Belgium. Biotechnologie, Agronomie, Société et Environnement 15(3):378-386

Morales-Irigoyen EE, de las Mercedes Gómez-y Y, Flores-Moreno JL, Franco-Hernández MO (2018) A bionanohybrid ZnAl-NADS ecological pesticide as a treatment for soft rot disease in potato (Solanum tuberosum L.). Environ Sci Pollut Res 25(22):21430-21439

Nasser W, Bouillant Marie L, Salmond G, Reverchon S (1998) Characterization of the Erwinia chrysanthemi expl-expR locus directing the synthesis of two $\mathrm{N}$-acyl-homoserine lactone signal molecules. Mol Microbiol 29(6):1391-1405

Nasser W, Dorel C, Wawrzyniak J, Van Gijsegem F, Groleau M-C, Déziel E, Reverchon S (2013) $\mathrm{Vfm}$ a new quorum sensing system controls the virulence of Dickeya dadantii. Environ Microbiol 15(3):865-880

Ngadze E (2018a) Calcium soil amendment increases resistance of potato to blackleg and soft rot pathogens. Afr J Food Agric Nutr Dev 18:12975-12991

Ngadze E (2018b) Calcium soil amendment increases resistance of potato to blackleg and soft rot pathogens. Afr J Food, Agric, Nutr Dev 18(1)

Ngadze E, Icishahayo D, Coutinho TA, van der Waals JE (2011) Role of polyphenol oxidase, peroxidase, phenylalanine ammonia lyase, chlorogenic acid, and total soluble phenols in resistance of potatoes to soft rot. Plant Dis 96(2):186-192

Ngadze E, Coutinho TA, Icishahayo D, van der Waals JE (2014) Effect of calcium soil amendments on phenolic compounds and soft rot resistance in potato tubers. Crop Prot 62:40-45

Olsen N, Thornton M, Nolte P (2012) Harvest Temperature Consequences. University of Idaho. https://idahopotato.com/uploads/media/harvest-temperature-consequences.pdf 
Ongena M, Jacques P, Touré Y, Destain J, Jabrane A, Thonart P (2005) Involvement of fengycintype lipopeptides in the multifaceted biocontrol potential of Bacillus subtilis. Appl Microbiol Biotechnol 69(1):29

Ongena M, Jourdan E, Adam A, Paquot M, Brans A, Joris B, Arpigny JL, Thonart P (2007) Surfactin and fengycin lipopeptides of Bacillus subtilis as elicitors of induced systemic resistance in plants. Environ Microbiol 9(4):1084-1090

Ossowicki A, Jafra S, Garbeva P (2017) The antimicrobial volatile power of the rhizospheric isolate Pseudomonas donghuensis P482. PLoS ONE 12(3):e0174362

Park SK (1969) Studies in the relationship between Ca nutrient and soft rot disease in Chinese cabbage, vol 12. Research Reports of Office of Rural Development 12(2):63-70

Park YH, Choi C, Park EM, Kim HS, Park HJ, Bae SC, Ahn I, Kim MG, Park SR, Hwang D-J (2012) Over-expression of rice leucine-rich repeat protein results in activation of defense response, thereby enhancing resistance to bacterial soft rot in Chinese cabbage. Plant Cell Rep 31(10):18451850

Pasco C, Bozec M, Ellissèche D, Andrivon D (2006) Resistance behaviour of potato cultivars and advanced breeding clones to tuber soft rot caused by Pectobacterium atrosepticum. Potato Res 49(2):91-98

Pavek JJ, Corsini DL (2001) Utilization of potato genetic resources in variety development. Am J Potato Res 78(6):433

Pérombelon MCM (1992) Potato blackleg: epidemiology, host-pathogen interaction and control. Tijdschrift Over Plantenziekten 98(2):135-146

Pérombelon MCM (2002) Potato diseases caused by soft rot erwinias: an overview of pathogenesis. Plant Pathol 51(1):1-12

Pérombelon MCM, Hyman LJ (1989) Survival of soft rot coliforms, Erwinia carotovora subsp. carotovora and E. carotovora subsp. atroseptica in soil in Scotland. J Appl Bacteriol 66(2):95-106

Pérombelon MCM, Kelman A (1980) Ecology of the soft rot Erwinias. Annu Rev Phytopathol 18(1):361-387

Pérombelon MCM, Salmond GPC (1995) Bacterial soft rot. In: Singh US, Singh RP, Kohmoto K (eds) Pathogenesis and host specificity in plant diseases. Pergamon Press. pp 1-20

Pérombelon MCM, Fox RA, Lowe R (1979) Dispersion of Erwinia carotovora in aerosols produced by the pulverization of potato haulm prior to harvest. J Phytopathol 94(3):249-260

Pérombelon M, Burnett E, Melvin J, Black S (1989) Preliminary studies on the control of potato blackleg by a hot water treatment of seed tubers. In: Vascular wilt diseases of plants. Springer, pp 557-566

Platero M, Tejerina G (1976) Calcium nutrition in Phaseolus vulgaris in relation to its resistance to Erwinia carotovora. J Phytopathol 85(4):314-319

Potato_Council (2009) Safe Haven certification scheme. https://potatoes.ahdb.org.uk/sites/default/ files/publication_upload/safe_haven_09.pdf

Pringle RT, Robinson K (1996) Storage of seed potatoes in pallet boxes. 1. The role of tuber surface moisture on the population of Erwinia bacteria. Potato Res 39(2):205-222

Rahman M, Ali ME, Khan A, Hashim U, Akanda A, Hakim M (2012) Characterization and identification of soft rot bacterial pathogens in Bangladeshi potatoes. Afr J Microbiol Res 6(7):1437-1445

Rakotonindraina T, Corbière R, Chatot C, Pinchon V, Dubois L, Aurousseau F, Chauvin JE, Aubertot JN (2011) Analysis of volunteer density under the influence of cropping practices: a contribution to the modelling of primary inoculum of Phytophthora infestans in potato crops. In: Thirteenth EuroBlight workshop, St. Petersburg, 2011. PPO-Special Report, vol 15. PPO-Special Report, pp 67-74

Ranganna B, Kushalappa AC, Raghavan GSV (1997) Ultraviolet irradiance to control dry rot and soft rot of potato in storage. Can J Plant Path 19(1):30-35

Ren J, Petzoldt R, Dickson MH (2001) Genetics and population improvement of resistance to bacterial soft rot in Chinese cabbage. Euphytica 117(3):197-207 
Rietman H, Finkers R, Evers L, van der Zouwen PS, van der Wolf JM, Visser RGF (2014) A stringent and broad screen of Solanum spp. tolerance against Erwinia bacteria using a petiole test. Am J Potato Res 91(2):204-214

Rivero M, Furman N, Mencacci N, Picca P, Toum L, Lentz E, Bravo-Almonacid F, Mentaberry A (2012) Stacking of antimicrobial genes in potato transgenic plants confers increased resistance to bacterial and fungal pathogens. J Biotechnol 157(2):334-343

Rojas F, Corzo L, Sánchez P, Brito D, Montes dO, Martínez Y, Pino P (2014) Antibacterial activity of essential oils against Pectobacterium carotovorum subsp. carotovorum. Revista de Protección Vegetal 29(3):197-203

Samson R, Legendre JB, Christen R, Fischer-Le Saux M, Achouak W, Gardan L (2005) Transfer of Pectobacterium chrysanthemi (Burkholder et al. 1953) Brenner et al. 1973 and Brenneria paradisiaca to the genus Dickeya gen. nov. as Dickeya chrysanthemi comb. nov. and Dickeya paradisiaca comb. nov. and delineation of four novel species, Dickeya dadantii sp. nov., Dickeya dianthicola sp. nov., Dickeya dieffenbachiae sp. nov. and Dickeya zeae sp. nov. Int J Syst Evol Microbiol 55:1415-1427

Schöber BM, Vermeulen T (1999) Enzymatic maceration of witloof chicory by the softrot bacteria Erwinia carotovora subsp carotovora : the effect of nitrogen and calcium treatment of the plant on pectic enzyme production and disease development. Eur J Plant Pathol 105:341-349

Schouten HJ, Krens FA, Jacobsen E (2006) Cisgenic plants are similar to traditionally bred plants: international regulations for genetically modified organisms should be altered to exempt cisgenesis. EMBO Rep 7(8):750-753

Simić M, Spasojević I, Kovacević D, Brankov M, Dragicević V (2016) Crop rotation influence on annual and perennial weed control and maize productivity. Rom Agric Res 33:125-132

Sjahril R, Chin DP, Khan RS, Yamamura S, Nakamura I, Amemiya Y, Mii M (2006) Transgenic Phalaenopsis plants with resistance to Erwinia carotovora produced by introducing wasabi defensin gene using Agrobacterium method. Plant Biotechnol 23(2):191-194

Sławiak M, van Beckhoven JR, Speksnijder AG, Czajkowski R, Grabe G, van der Wolf JM (2009) Biochemical and genetical analysis reveal a new clade of biovar 3 Dickeya spp. strains isolated from potato in Europe. Eur J Plant Pathol 125(2):245-261

Smid EJ, Jansen AHJ, Tuijn CJ (1993) Anaerobic Nitrate respiration by Erwinia carotovora subsp. atroseptica during potato tuber invasion. Appl Environ Microbiol 59(11):3648-3653

Snijder Ronald C, van Tuyl Jaap M (2002) Evaluation of tests to determine resistance of Zantedeschia spp. (Araceae) to soft rot caused by Erwinia carotovora subsp. carotovora. Eur J Plant Pathol 108(6):565-571

Spooner DM, Jansky SH, Simon R (2009) Tests of taxonomic and biogeographic predictivity: resistance to disease and insect pests in wild relatives of cultivated potato. Crop Sci 49(4):13671376

Stewart D, McDougall GJ, Ross HA, Hancock RD, Morris WL, Taylor MA, Roberts AG, Wright KM, Chapman SN, Tucker GA, James EK (2010) Potato tuber pectin structure is influenced by pectin methyl esterase activity and impacts on cooked potato texture. J Exp Bot 62(1):371-381

Thangavel T, Steven Tegg R, Wilson CR (2014) Resistance to multiple tuber diseases expressed in somaclonal variants of the potato cultivar russet Burbank. The Sci World J 2014:8

Toth IK, Newton JA, Hyman LJ, Lees AK, Daykin M, Ortori C, Williams P, Fray RG (2004) Potato plants genetically modified to produce $\mathrm{N}$-acylhomoserine lactones increase susceptibility to soft rot Erwiniae. Mol Plant Microbe Interact 17(8):880-887

Toth IK, Hyman LJ, Moleleki L, Ravensdale M, Robert C, Liu H, Humphris S, Hedley P, Gilroy E, Pritchard L, Birch PRJ (2006) What has genomics ever done for us?-a study of Erwinia and blackleg disease. In: Crop protection in Northern Britain, Dundee, Frebuary, 2006

Toth IK, van der Wolf JM, Saddler G, Lojkowska E, Helias V, Pirhonen M, Tsror L, Elphinstone JG (2011) Dickeya species: an emerging problem for potato production in Europe. Plant Pathol 60(3):385-399 
Tsror L, Erlich O, Lebiush S, Hazanovsky M, Zig U, Slawiak M, Grabe G, van der Wolf JM, van de Haar JJ (2009) Assessment of recent outbreaks of Dickeya sp (syn. Erwinia chrysanthemi) slow wilt in potato crops in Israel. Eur J Plant Pathol 123(3):311-320

Tsror L, Lebiush S, Erlich O, Ben-Daniel B, Van der Wolf J (2010) First report of latent infection of Cyperus rotundus caused by a biovar 3 Dickeya sp.(Syn. Erwinia chrysanthemi) in Israel. New Dis Rep 22(14):2044-0588

Tsuda K, Tsuji G, Higashiyama M, Ogiyama H, Umemura K, Mitomi M, Kubo Y, Kosaka Y (2016) Biological control of bacterial soft rot in Chinese cabbage by Lactobacillus plantarum strain BY under field conditions. Biol Control 100:63-69

Tyc O, van den Berg M, Gerards S, van Veen JA, Raaijmakers JM, De Boer W, Garbeva P (2014) Impact of interspecific interactions on antimicrobial activity among soil bacteria. Front Microbiol 5:567

Tzeng KC, McGuire RG, Kelman A (1990) Resistance of tubers from different potato cultivars to soft rot caused by Erwinia carotovora ssp atroseptica. Am Potato J 67(5):287-306

Van Doorn J, Vreeburg PJM, van Leeuwen PJ, Dees RHL (2011) The presence and survival of soft rot (Erwinia) in flower bulb production systems. Acta Hort 886:365-379

Vanjildorj E, Song SY, Yang ZH, Choi JE, Noh YS, Park S, Lim WJ, Cho KM, Yun HD, Lim YP (2009) Enhancement of tolerance to soft rot disease in the transgenic Chinese cabbage (Brassica rapa L. ssp. pekinensis) inbred line, Kenshin. Plant Cell Rep 28(10):1581-1591

Vantomme R, Sarrazyn R, Goor M, Verdonck L, Kerstcrs K, De Ley J (1989) Bacterial rot of witloof chicory caused by strains of Erwinia and Pseudomonas: symptoms, isolation and characterisation. J Phytopathol 124:337-367

van Vuurde JWL, de Vries PM (1994) Population dynamics of Erwinia carotovora subsp. atroseptica on the surface of intact and wounded seed potatoes during storage. J Appl Bacteriol 76(6):568-575

Wale S, Kiezebrink D, Anderson E, Dawson G, Toth I, Humphris S, McKenzie K (2013) Evaluating the impact of haulm destruction method on the development of disease in seed tuber production, vol R453. Potato Council, Kenilworth, UK

Wastie RL, Mackay GR, Carbonell J (1994) Effect of Erwinia carotovora subsp. atroseptica on yield of potatoes from cut and uncut seed tubers in Valencia. Potato Res 37(1):21-24

Wegener CB (2002) Induction of defence responses against Erwinia soft rot by an endogenous pectate lyase in potatoes. Physiol Mol Plant Pathol 60(2):91-100

Wegener C, Bartling S, Olsen O, Weber J, von Wettstein D (1996) Pectate lyase in transgenic potatoes confers pre-activation of defence against Erwinia carotovora. Physiol Mol Plant Pathol 49(6):359-376

White PJ, Broadley MR (2003) Calcium in plants. Ann Bot 92(4):487-511

Wicks TJ, Hall BH, Morgan BA (2007) Tuber soft rot and concentrations of Erwinia spp. in potato washing plants in South Australia. Australas Plant Pathol 36(4):309-312

Wright P, K. Burge G, (2000) Irrigation, sawdust mulch, and enhance biocide affects soft rot incidence, and flower and tuber production of calla. New Zealand J Crop Hortic Science 28:225231

Zimnoch Guzowska E, Marczewski W, Lebecka R, Flis B, Schaefer Pregl R, Salamini F, Gebhardt C (2000) QTL analysis of new sources of resistance to Erwinia carotovora ssp. atroseptica in potato done by AFLP, RFLP, and resistance-gene-like markers. Crop Sci 40(4):1156-1167 